\title{
Laboratory Weathering and Solubility Relationships of Fluorine and Molybdenum in Combusted Oil Shale
}

\section{Topical Report}

M.E. Essington

R.A. Wills

M.A. Brown

January 1991

Work Performed Under Cooperative Agreement No.: DE-FC21-86MC11076

For

U.S. Department of Energy

Office of Fossil Energy

Morgantown Energy Technology Center

Morgantown, West Virginia

By

Western Research Institute

Laranie, Wyoming

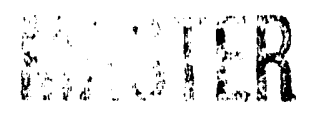




\section{DISCLAIMER}

This report was prepared as an account of work sponsured by an agency of the United States Government. Neither the United States Government nor any agency thercof, nor any of their employees makes any warranty, express or implied, or assumes any legal liability or responsibility for the accuracy, completeness or usefulness of any information, apparatus, product, or process disclosed, or represents that its use would not infringe privately owned rights. Reference herein to any specific commercial product, process, or service by trade name, trademark, manufacturer, or otherwise, does not necessarily constitute or imply its endorsement, recommendation, or favoring by the United States Government or any agency thereof. The views and opinions of authors expressed herein do not necessarily state or reflect those of the United States Government or any agency thereof.

This report has been reproduced directly from the best available copy.

Available to DOE and DOE contractors from the Office of Scientific and Technical Information, P.O. Box 62, Oak Ridge, TN 37831; prices available from (615)576-8401, FTS 626-8401.

Available to the public from the National Technical Information Service, U.S. Department of Commerce, 5285 Port Royal Rd., Springlield, VA 22161. 


\title{
Laboratory Weathering and Solubility Relationships of Fluorine and Molybdenum in Combusted Oil Shale
}

Topical Report

M.E. Essington

R.A. Wills

M.A. Brown

Work Performed Under Cooperative Agreement No.: DE-FC21-86MC11076

For

U.S. Department of Energy

Office of Fossil Energy

Morgantown Enel gy Technology Center

P.O. Box 880

Morgantown, West Virginia 26507-0880

\author{
By \\ Western Research Institute \\ P.O. Box 3395 \\ University Station \\ Laramie, Wyoming 82071
}

January 1991 


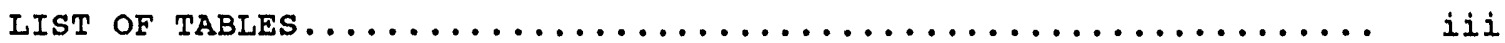

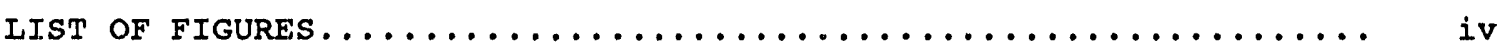

SUMMARY $\ldots \ldots \ldots \ldots \ldots \ldots \ldots \ldots \ldots \ldots \ldots \ldots \ldots \ldots \ldots \ldots \ldots \ldots \ldots \ldots \ldots \ldots$

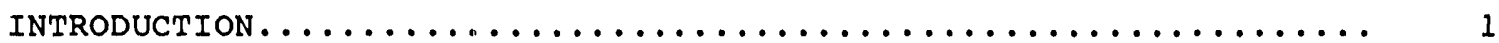

MATERIALS AND METHODS............................ 4

Sample preparation............................... 4

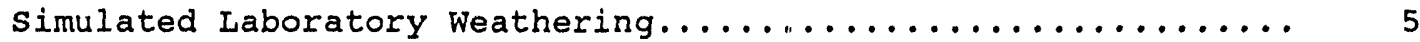

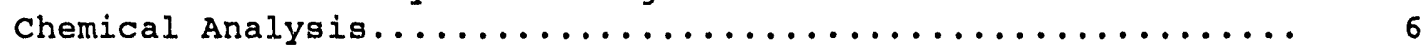

Mineralogical Analysis.......................... 6

Geocheraical Model Analysis......................... 6

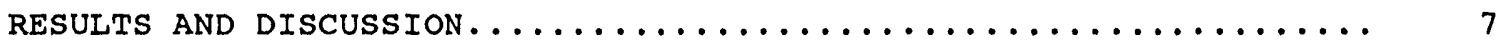

Mineralogy................................... 7

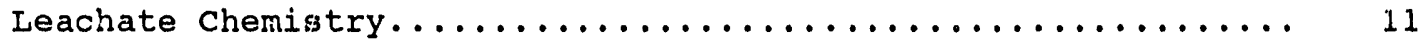

Batch Equilibrium Solubility Relationships............... 16

simulated Equilibrium weathering.................... 21

CONCLUSIONS..................................... 24

ACKNOWLEDGEMENTS. ................................ 26

DISCLAIMER .................................. 26

REFERENCES..................................... 27

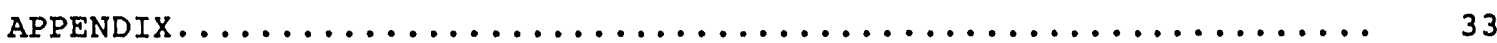




\section{LIST OF TABLES}

\section{Table}

Page

1. Mineralogy of Green River Formation oil shale and New Albany shale (modified from Miknis and Robertson 1987)...... 4

2. Chemical Reactions and Association Constants used by

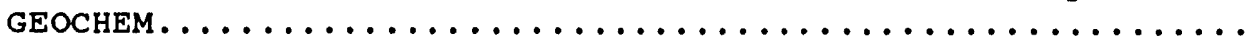

3. Mineralogy of Nonweathered and Weathered Processed

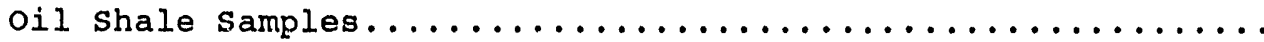

4. Mean Chemical Characteristics of Triplicate Samples of

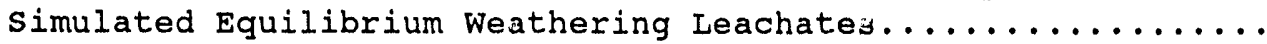


1. $\mathrm{pH}$ (a) and EC (b) of Humidity Cell Leachates from Combusted (CW) and Lurgi-Ruhrgas Processed (LR) Green River Formation Oil Shale and Combusted

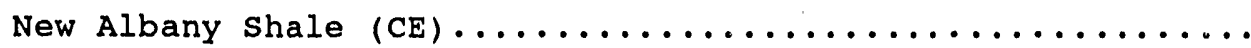

2. Chemical Characteristics of Humidity Cell Leachates from Combusted Green River Formation oj.l Shale............

3. Chemical Characteristics of Humidity Cell Leachates from Lurgi-Ruhrgas Processed Green River Formation

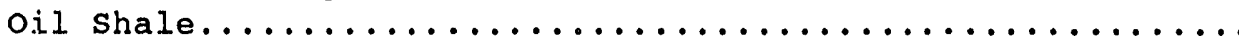

4. Chemical Characteristics of Humidity Cell Leachates

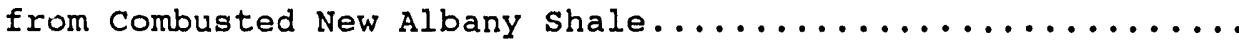

5. Powellite Ion Activity Product Values as a Function of

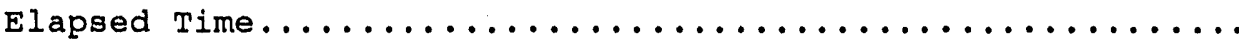

6. Fluorite Ion Activity Product Values as a Function of

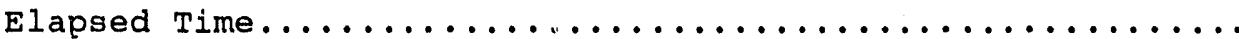

7. Powellite Ion Activity Product Values as a Function of

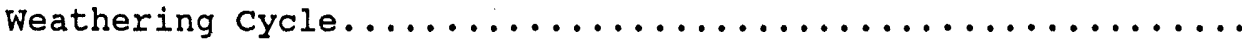

8. Fluorite Ion Activity Product Values as a Function of

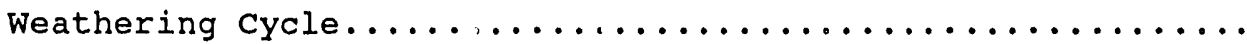




\section{SUMMARY}

Iroper management of large volumes of spent oil shale requires an understanding of the mineralogy and the disposal environment chemistry. simulated laboratory weathering is one method to rapidly and inexpensively assess the long-term potential for spent oil shales to degrade the environment. The objectives of this study were to assess the solubility relationships of fluorine (F) ard molybdenum (Mo) in Green River Formation spent oil shale, to examine the mineralogy and leachate chemistry of three combusted oil shales in a laboratory weathering environment using the humidity cell technique, and to examine the data from spent oil shale literature. Combusted oil shales from the Green River Formation and New Albany shale were used in the examination of the leachate chemistry and mineralogy.

Combusted western oil shale mineralogy is dopendent on the process conditions. In general, the process will result in the formation of anhydrite, lime, periclase, and hematite. During the initial stages of weathering, lime, periclase, and anhydrite dissolve and calcite precipitates. Also, ettringite precipitates during the initial weathering stages. In western disposal environments spent oil shale will remain in the initial stages of weathering, and highly alkaline and saline conditions will dominate the leachate chemistry. A leachate $\mathrm{pH}$ of 12.0 is rapidly reduced to between 8.5 and 9.0 with leaching.

The combusted eastern oil shale is composed of quartz, illite, hematite, and orthoclase. In an eastern disposal environment, soluble salts will be rapidly removed from the spent oil shale to potentially affect the surrounding environment. The combusted eastern oil shale did not display a potential to produce acid drainage. Leachate chemistry was dominated by $\mathrm{Ca}$ and $\mathrm{SO}_{4}$, and the element concentrations decreased with weathering.

Fluorine and Mo may adversely affect vegetation, grazing animals, groundwater, and surface waters that are proximate to spent oil shale disposal environments. The chemistry of $F$ and Mo in spent oil shale leachates may be controlled by the precipitation of fluorite $\left(\mathrm{CaF}_{2}\right)$ and powellite $\left(\mathrm{CaMOO}_{4}\right)$, respectively. Thus, the fate and behavior of these elements may be predicted using equilibrium solubility methods.

Recent findings and the examination of methods cast dorbt on the interpretations of many spent oil shale solubility studies. Recent research shows that the formation of soluble molybdate species in spent oil shale leachates can be significant. Further, reaction times necessary to achieve equilibrium conditions were not attained in many solubility experiments. Also, most of the solubility experiments were only performed on fresh solid waste, yielding little information on element behavior in a disposal environment. Examination of the literature data on ion association models suggests that $F$ is present as $\mathrm{CaF}_{2}$ in spent oil shale. However, spent oil shale leachates are undersaturated with respect to $\mathrm{CaMOO}_{4}$. During the initial cycles of the equilibrium weathering study, the solubility relationships for $F$ and Mo were similar to those found in the literature. As weathering progressed, the spent oil shale leachates became supersaturated with 
respect to fluorite and saturated with respect to powellite. These results indicate that in a weathering spent oil shale environment, subject to the slow infiltration of water, the behavior of Mo may be predicted on the basis of powellite solubility. However, $\mathrm{F}$ behavior can not be predicted due to the fact that the system becomes supersaturated over time as a result of an unknown factor. The leachate should not become supersaturated with $\mathrm{F}$ if $\mathrm{CaF}_{2}$ is present and equilibrium exists. 


\section{INTRODUCTION}

Spent oil shale is the solid waste product that results from the production of synthetic crude oil during the thermal alteration of oil shale. A commercial-gcale shale oil operation will generate large quantities of solid waste materials. The Unocal operation at Parachute, Colorado, produced $95,400 \mathrm{~m}^{3}$ of synthetic crude oil and $675,000 \mathrm{t}$ of spent oil shale in 1987 from a shale ore averaging 558 of design capacity (Knutson et al. 1988). Routson et al. (1979) estimated that the production of spent oil shale from a mature shale oil industry would exceed $1 \times 10^{12}$ grains per day.

spent oil shale mineralogy is a function of the raw oil ghale properties (e.g., mineralogy, grain size, organic matter content) and the process parameters (e.g., heating rate, maximum temperature and duration, gas composition, porosity) (Campbell and Burnham 1978; Park et al. 1979; Williamson et al. 1980). The mineralogy of the raw oil shale and the oil shale processing parameters are factors that directly influence spent oil shale leachate chemistry. In general, the heatinduced mineral alterations that occur during the processing of oil shale result in a suite of minerals, principally alkaline earth oxides and silicates, that generate highly alkaline and saline leachates. Batch extraction and laboratory column studies are commonly employed to rapidly assess the potential for spent oil shale to generate leachates that contain elevated levels of potentially hazardous elements, salinity, sodicity, and alkalinity (or acidity) (Fransway and wagenet 1981; Grant et al. 1981; Koppenaal et al. 1981; Stollenwerk and Runnells 1981; Saffer et al. 1982; Tian and Ehmann 1984; Jones 1990). Although batch extraction tests provide valuable information, there are a number of inherent limitations with respect to the applicability of the results (Jones 1990). The tests do not allow for the assessment of leachate and mineralogical character as a function of exposure in a weathering environment, and the data obtained are only applicable to the waste at that particular stage of weathering.

Batch extraction tests that impose artificial conditions to simulate the long-term release of elements (e.g., TCLP extraction, acid leaching, chelate leaching) may produce ambiguous results (Esmaili et al. 1985; Essington and Carroll 1985; Jones 1990). Such artificial conc $\because$ ions do not allow for the natural progression of weathering, denoted by the dissolution of unstable minerals, the migration of soluble salts, and the precipitation of stable minerals. Such reactions are significant with respect to spent oil shale, due to their inheren'i instability, and may result in the fixation or the slow release of e.'ements (Esgington 1989 a).

Leachates from field lysimeters or actual spent oil shale disposal sites, as well as the weathered solids, have also been examined (Garland et al. 1979; Richardson et al. 1981; Tuttle et al. 1985; Robl et al. 1985, 1986, 1987; stark and Redente 1986,1990a, b). Field studies provide tise most relevant information on solid waste behaviol in a disposal environment. However, such studies are time consuming and costly, and it may take decades before spent oil shale leachates affect the surrounding environment. For example, Tuttle et al. (1985) 
determined the mineralogy and elemental abundances for a 50-year-old retorted oil shale waste disposal pile at an experimental retort facility in Rulison, colorado. They reported that limited changes had occurred over the past 50 years, as weathering products were only observed at shallow depths in the disposal pile.

The alkalinity, salinity, and potentially hazardous element composition of a spent oil shale leachate are influenced by the mineralogy of the solid waste material. Further, the leachability of these components is a function of the hydrology of the disposal pile (e.g., annual pracipitation). Thus, methods that adequately assess the long-term potential for the solid waste material to adversely affect the environment must include a mechanism to examine waste behavior on a waste-specific and site-specific basis. Relatively short-term, costeffective procedures for such an evaluation include the soxhlet and the humidity cell weathering procedures (Caruccio 1968; sobek et al. 1982). These methods are relatively short-term and can generate trends in mineralogical alterations and trends in leachate behavior (as a function of time) that may occur in a field environment under a variety of conditions. Oil shale, spent oil shale, and coal refuse and overburien have been subjected to laboratory weathering using these and similar methods, primarily to assess acid drainage potential (Koppenaal et al. 1981; Sullivan and Sobek 1982; Sullivan et al. 1986, 1987a, b). one of the objectives of the present study is to use the humidity cell laboratory weathering technique to examine combusted western (Green River Formation) and eastern (New Albany Shale) oil shale mineralogy and leachate chemistry as a function of relative time in a nonequilibrium, unsaturated leaching environment.

Potentially toxic levels of molybdenum (Mo) and fluorine (F) leached from spent oil shale disposal environments may adversely affect vegetation, grazing animals, groundwater, and surface waters. Molybdenum is an essential plant micronutrient; it can be accumulated in plant tissue without phytotoxic effects to levels that are toxic to grazing animals. Plant uptake of Mo from soils is directly correlated to Mo concentrations in soil solutions (Adriano 1986; Albasel and Pratt 1989). Correspondingly, plants grown on spent oil shale may accumulate Mo as a result of elevated Mo concentrations in spent oil shale solutions. Indeed, the concentrations of Mo and $\mathrm{Cu} / \mathrm{Mo}$ ratios in plants grown on spent oil st ale suggest that molybdenosis can be expected in grazing animals (F.1kelly and Lindsay 1982; Schwab et al. 1983; Reddy and Lindsay 1987; Stark and Redente 1990a, b).

Fluorine has not been shown to be an essential plant nutrient but may be concentrated in plant tissue without phytotoxic effects to levels that can cause fluorosis in grazing animals (Adriano 1986). Plants grown on spent oil shale, recarbonated spent oil shale, and topsoil $(<30$ $\mathrm{cm}$ ) over spent oil shale may accumulate F (Kilkelly and Lindsay 1982; schwab et al. 1983; Reddy and Lindsay 1987; Stark and Redente 1990a). However, plant tissue $F$ concentrations are well below those deemed hazardous to animals. 'Ihe primary concern associated with $F$ in spent oil shale disposal environments is the potential for this element to leach to groundwater environments. Fluorine is mobile (stark and 
Redente 1986); unlike Mo, the spent oil shale has a capacity to regenerate elevated leachate $F$ concentrations. It is imperative to understand the processes controlling $F$ and Mo aqueous and solid-phase distribution. In order to understand the chemistry of $F$ and $M o$ in spent oil shale disposal environments it is necesgary to predict fate and behavior and assess the effectiveness of proposed mitigation techniques (e.g., recarbonation).

Several methods have been used to identify Mo- and F-bearing solid phases in spent oil shale. Essington (1989a), using a selective sequential extraction technique, concluded that Mo was associated with chemically resistant, nonextractable solid phases (Fe oxides, Fe sulfides, and aluminosilicates). These results were supported by spackman and Essington (1988). They statistically examined the partitioning of elements into spent oil shale density separates and concluded that Mo was associated with Fe-bearing minerals. In contrast, equilibrium solubility measurements have suggested that the the precipitation of powellite $\left(\mathrm{CaMoO}_{4}\right)$ and fluorite $\left(\mathrm{CaF}_{2}\right)$ control the leachate concentrations of Mo and $F$ (Saether and Runnells 1980; Stollenwerk and Runnells 1981; Essington and Spackman 1986; Essington et al. 1987; Essington 1987; Reddy and Hasfurther 1989).

one prcblem associated with spent oil shale solubility studies is the lack of relevant thermodynamic data necessary to describe aqueous speciation. Essington (1990a, 1991) and Essington and Huntington (1990) determined the ion association constants for the formation of $\mathrm{CaMoO}_{4}{ }^{0}$, $\mathrm{MgMOO}_{4} \mathrm{O}^{\circ} \mathrm{KMOO}_{4}^{-}$, and $\mathrm{NaMOO}_{4}^{-}$and the equilibrium solubility of powellite. Application of these data to geochemical models suggested that spent oil shale leachates were highly undersaturated with respect to powellite and resulted in the conclusion that powellite did not control soluble Mo concentrations. Essington $(1990 \mathrm{a})$ reported that the sum of the concentrations of alkaline earth and alkali metal molybdate ion pairs accounted for more than 508 of the total soluble Mo in spent oil shale leachates. This finding showed the significance of ion pairs and the potential errors involved in data interpretations when they are not considered. Essington (1990a) also noted that an equilibration period greater than 28 days was required to obtain constant ion activity products in the powellite solubility studies. However, few of the studiea cited above used equilibration times approaching 28 days.

The equilibrium solubility method, despite its shortcomings, can provide useful information on the phases controlling solution chemistry. Historically, spent oil shale equilibrium solubility studies have been performed using fresh solid waste materials to assess Mo and $F$ leachate and mineralogical character. However, these studies do not examine solubility relationships as a function of exposure in a weathering environment. Thus, changes in Mo and $F$ solid-phase chemistry with spent oil shale weathering have not been adequately assessed.

There are three objectives to the present study: (1) to use the humidity cell simulated weathering technique to examine combusted western (Green River Formation) and eastern (New Albany Shale) oil shale mineralogy and leachate chemistry as a function of relative time in a nonequilibrium, unsaturated leaching environment; (2) to reexamine the 
an overall understanding of the Mo and $F$ solubility relationships in spent oil shale; and (3) to examine the solubility relations of Mo and $F$, in Green River Formation oil shale, as a function of relative time in an equilibrium leaching environment using a simulated weatherin's technique.

\section{MATERIALS AND METHODS}

\section{Sample Preparation}

Green River Formation oil shale from the Piceance Creek Basin was obtained from the Exxon Colony oil shale Mine near Parachute, Colorado. Clegg Creek Member, New Albany shale was obtained from the knieriem quarry located approximately 16 milas south of the ohio River at Louisville, Kentucky. The mineralugy (Table 1) of the Green River Formation oil shale and the New Aluany shale is described by Miknis and Robertson (1987).

Table 1. Mineralogy of Gieen River Formation Oil shale and New Albany Shale (modified from Miknis and Robertson 1987)

Green River Formation New Albany shale

$\begin{array}{ll}\text { Quarcz } & \text { Quartz } \\ \text { Ankerite } & \text { Illite } \\ \text { Calcite } & \text { Smectite } \\ \text { Dawsonite } & \text { Pyrite } \\ \text { Feldspar } & \text { Feldspar } \\ \text { Mg-siderite } & \text { Kaolinite/Chlorite } \\ \text { Pyrite } & \text { Calcite }\end{array}$

Minerals listed in decreasing order of abundance

The combusted Green River Formation oil shale (designated CW) was produced in a fluidized-bed reactor using $\mathrm{CO}_{2}$ as the retort gas, air as the combustion gas, an average retorting shale bed temperature of $570^{\circ} \mathrm{C}$ $\left(1058^{\circ} \mathrm{F}\right)$, an average combustion bed temperature of $610^{\circ} \mathrm{C}\left(1130^{\circ} \mathrm{F}\right)$ and a residence time of 5 minutes. The combusted New Albany shale (designated CE) was also produced in a fluidized-bed reactor using $\mathrm{CO}_{2}$ and air as the retort and combustion gases, an avorage retort bed temperature of $580^{\circ} \mathrm{C}\left(1076^{\circ} \mathrm{F}\right)$, an average combistion bed temperature of $640^{\circ} \mathrm{C}\left(1184^{\circ} \mathrm{F}\right)$, and a residence time of 5 minutes (Merriam et al. 1987) A second processed Green River Formation oil shale sample (designated LR) was obtained from the Rio 31 anco oil shale company Inc., Tract C-a, Colorado. The retorted $0 \perp l$ shale was produced by the lurgi-Ruhrgas process using air as the process gas and a temperature of approximately $530^{\circ} \mathrm{C}\left(986^{\circ} \mathrm{F}\right)$. Rammler (1982) describes the Lurgi-Ruhrgas process for the retorting of oil shale. 


\section{Simulated Laboratory Weathering}

The spent oil shale samples were very friable and, when necessary, were lightly ground to pass a $2-m m$ sieve and riffled to obtain representative sample materials for the study. For the laboratory weathering experiment, subsamples of the CW, CE, and LR materials were subjected to nonequilibrium weathering using the humidity cell technique (Caruccio 1968; Sullivan et al. 1987b). Duplicate, 1.0-kg samples of each spent oil shale were sealed in Teflon-coated containers. Dry air was passed over the samples for three days. Humidified air was then passed over the samples for four days. On the seventin day, $1 . i$ L of Milli-Q reagent-grade, Type I water (Millipore Corp., Bedford, MA) was added to the spent oil shale samples and allowed to react for one hour. Type I water was added to the system to maintain a $1: 1$ solid-to-solute extraction ratio. The solution and solid phases were separated by sequential vacuum filtrati,n through whatman 42 filter paper (Whatman, Maidstone, England) and a $0.45-\mu \mathrm{m}$ Millipore filter (Iiilipore Corp., Bedford, $M A)$. The leachates were subjected to chemical analysis, and the solids were returned to the reaction vessel and allowed to dry at room temperature. Humidified air was then passed over the samples for seven days and the extraction was repeated. The seven-day weathering cycle continued for 18 weeks.

$F$ and Mo solubility relationships were evaluated by subjecting the $\mathrm{CW}$ and IR materials to equilibrium laboratory weathering using a modified batch technique. Triplicate, 250.0-g samples of each spent oil shale and 0.5 I of Milli-Q reagent-grade, Type I water (Millipore Corp., Bedford, MA) were placed in 1,0-L polypropylene bottles. Each bottle was equipped with a 2-hole Neoprene rubber stopper. A glass tube was placed through one hole to disperse humidified air to the bottom of the bottle. A glass tube was placed through the second hole for sxhaust. The bottles were tightly stoppered and placed in a $25.0 \pm 0.1^{\circ} \mathrm{C}(77 \pm$ $1.8^{\circ} \mathrm{F}$ ) water bath. Humidified air was bubbled through the reaction vessels for a 28-day equilibration period. During this poriod, the bottles were manually agitated 5 minutes per day, and the weight of each bottle was monitored and maintained by the addition of Type I water.

Upon completion of the first equilibration cycle, the soiution and solid phases were separated by sequential vacuum filtration through Whatman 42 filter paper and a $0.45-\mu \mathrm{m}$ membrane filter. The leachates were analyzed, and the solids were air-dried and returned to the reaction vesselis. A sufficient volume of Type I water was added to each bottle to make a $1: 2$ solid-to-solute ratio. The suspensions were vigorously shaken, stoppered, and humidified air was bubbled through the reaction vessel for a second 28-day equilibration period. At the completion of the second cycle, the lpachates were sampled as before, the solids returned to the reaction vessels, and the cycle repeater. The spent oil shale samples were weathered for a total of six equilibration cycles.

\section{Chemical Analysis}

The methods of chemical analysis for both the laboratory weathering and the Mo and $F$ solubility relationship experiments were similar. 


\section{Chemical Analysis}

The methods of chemical analysis for both the laboratory weathering and the Mo and $F$ solubility relationship experiments were similar. After separation and before filtration, leachate $\mathrm{pH}$ was determined with a standardized combination $\mathrm{pH}$ electrode ( $\mathrm{pH} 7$ and 10) and a corning model 255 pH/ion meter (Corning science products, Corning, NY) Leachate electrical conductivity (EC) was determined with a YSI model 3403 conductivity cell $\left(\mathrm{K}=1.0 \mathrm{~cm}^{-1}\right)$ and a YSI model 34 conductivity resistance meter (YSI, Yellow springs, OH). After filtration, the leachate samples were split, and subsamples were analyzed for $F_{1}, B_{,} B a$, $\mathrm{Ca}, \mathrm{Fe}, \mathrm{K}, \mathrm{Li}, \mathrm{Mg}, \mathrm{Mn}, \mathrm{Mo}, \mathrm{Na}, \mathrm{Si}, \mathrm{Sr}, \mathrm{V}$, and $\mathrm{zn}$ by inductively coupled plasma (ICP) using a Jarrell-Ash 1100 spectrometer (Jarrell-Ash Corp., Franklin, MA). In the solubility relationship study, only $\mathrm{Al}, \mathrm{Ca}, \mathrm{K}$, $\mathrm{Mg}$, Mo, Na, and Si were ana?yzed by ICP. subsamples for ICP analysis were predigested by refluxing in $\mathrm{KNO}_{3}$. standard solutions for ICP analysis were prepared from ultrahigh-purity-grac'e chemicals or metals and verified against EPA7 and EPA19 reference solutions. During the study, the prepared standards were within $\pm 10 \%$ of the reference solutions. Spectral interference and background correction factors were verified by spike recovery analysis and analysis of diluted samples. spiked and diluted samples were within \pm 108 of the sample results.

The subsamples were also analyzed by ion chromatography for $F$, $\mathrm{Cl}, \mathrm{NO}_{3}, \mathrm{CO}_{3}, \mathrm{SO}_{4}$, and $\mathrm{s}_{2} \mathrm{O}_{3}$ with a Dionex model $4040 \mathrm{i}$ dual-channel ion chromatograph (Dionex Corp., sunnyvale, CA). Standard solutions were prepared using ultrahigh-purity-grade salts. For any given ion, the coefficient of variation for multiple analyses of a single sample was within \pm 108 .

\section{Mineralogical Analysis}

Subsamples of the weathered spent oil shales were obtained from the humidity cells prior to extractions 2,5 , and 8 . Bulk mineralogy of the spent oil shale and weathered spent oil shale samples was determined by $x-r a y$ diffraction analysis (XRD) using a scintag PAD $V$ diffractometer (Scintag, santa Clara, CA). X-ray analysis was performed on randomly oriented samples using $\mathrm{Ni}$-filtered Cuka radiation at $45 \mathrm{kV}$ and $40 \mathrm{~mA}$. Samples were scanned from 2 to $65^{\circ}$ at $2 \theta \mathrm{min}^{-1}$. The XRD profiles were interpreted by manual interaction with scintag software containing Joint committee on Powder Diffraction standards files. The chemical formulas of minerals discussed in the text are listed in the Appendix.

\section{Geochemical Model Analyais}

The activities of $\mathrm{F}^{-}$and $\mathrm{MOO}_{4}{ }^{2-}$ were predicted using the model GEOCHEM (Sposito and Mattigod 1980). The pH and total metal and anion concentrations of extracts from weathered spent oil shale were used as input data for the geochemical code. The code calculates the free ionic and ion pair species distributions by numerically solving a set of coupled nonlinear algebraic equations by successive iterations. Each equation relates total soluble element concentrations to free ionic and ion pair species concentrations using the appropriate conditional stability constants and stoichiometry. Ionic strength corrections and 
species activity calculatıons were performed using the Davies or the Debye-Hückel limiting law equations for charged species and the Setchenow-Harned-Owen equation for neutral species. The GEOCHEM thermodynamic data base was altered to include species important in highly alkaline solutions (e.g., $\mathrm{HSiO}_{4}{ }^{-}$, $\left.\mathrm{SiO}_{4}{ }^{-}\right)$, , soluble molybdate species $\left(\mathrm{NalMOO}_{4}{ }^{-}, \mathrm{CaMOO}_{4}{ }^{\circ}, \mathrm{MgMoO}_{4}{ }^{0}\right)$, and critically evaluated data. The pertinent chemical reactions and association constants used in the model computations are listed in Table 2 .

The activities of $\mathrm{Ca}, \mathrm{F}$, and $\mathrm{MOO}_{4}$ predicted by GEOCHEM were used to calculate ion activity product (IAP) values for fluorite ( $\mathrm{CaF}_{2}$ ) and powellite $\left(\mathrm{CaMOO}_{4}\right)$. For $\mathrm{CaF}_{2}$ and $\mathrm{CaMOO}_{4}$, the IAP is equal to $\left(\mathrm{Cl}^{2+}\right)\left(\mathrm{F}^{-}\right) 2$ and $\left(\mathrm{Ca}^{2+}\right)\left(\mathrm{MOO}_{4}^{2-}\right)$, respectively. The IAP values were compared to the equilibrium solubility product constants $\left(\mathrm{K}_{\mathrm{sp}}\right)$ for powellite $\left(\log \mathrm{K}_{\mathrm{gp}}=-7.86 ;\right.$ Essington and Huntington 1990$)$ and fluorite $\left(\log \mathrm{K}_{\mathrm{sp}}=-10.96 ;\right.$ Nordstrom and Jenne 1977) to identify the saturation status of the spent oil shale solutions. Undersaturation is predicted when the calculated IAP value is less than $\mathrm{K}_{\mathrm{sp}}$ and suggests that the mineral will dissolve if present. Supersaturation is predicted when the calculated IAP value is greater than $k_{\mathrm{sp}}$ and suggests that the mineral will precipitate. When the calculated IAP is equal to the $\mathrm{k}_{\mathrm{sp}}$ and a condition of equilibrium can be established, the mineral is predicted to be present and controlling the solution activities of its component ions.

In addition to the data generated from the spent oil shale laboratory weathering extractions, several data sets associated with spent oil shale solutions were chosen from the literature for ion association model examination. The data sources were saether and Runnells (1980), Stollenwerk and Runnells (1981), Esmaili et al. (1985), Essington and Spackman (1986 and 1988), Reddy and Lindsay (1986), Reddy et al. (1986), Essington et al. (1987), Reddy and Hasfurther (1989), and Essington (1990a). The chemical characteristics of these solutions were input to the GEOCHEM code. To account for the formation of soluble molybdate complexes and provide comparable results across all data sets, it was necessary to reevaluate the data in the literature using a single thermodynamic data base.

\section{RESULTS AND DISCUSSION}

\section{Mineralogy}

The mineralogies of the combusted oil shale samples as a function of weathering cycles are listed in Table 3 . Before weathering, the mineralogy of the $\mathrm{CW}$ sample was dominated by silicate (quartz, plagioclase), alkaline earth oxide (lime, periclase), and carbonate (calcite, ankeritic dolomite) minerals. Pyrite, present in the raw oil shale, was converted to hematite (as was ankeritic dolomite), and the $\mathrm{SO}_{2}$ released during the combustion process was captured by calcite to form anhydrite (Smith et al. 1978; Williamson et al. 1980). 
Table 2. Chemical Reactions and Association Constants used by GEOCHEMa

\begin{tabular}{|c|c|}
\hline Reaction & $\log K$ \\
\hline $\mathrm{Ca}^{2+}+\mathrm{CO}_{3}^{2-}=\mathrm{CaCO}_{3}^{0}$ & 3.2 \\
\hline $\mathrm{Ca}^{2+}+\mathrm{H}^{+}+\mathrm{CO}_{3}^{2-}=\mathrm{CaHCO}_{3}^{+}$ & 11.4 \\
\hline $\mathrm{Ca}^{2+}+\mathrm{SO}_{4}^{2-}=\mathrm{CaSO}_{4}^{0}$ & 2.3 \\
\hline $\mathrm{Ca}^{2+}+\mathrm{F}^{-}=\mathrm{CaF}^{+}$ & 1.1 \\
\hline $\mathrm{Ca}^{2+}+\mathrm{H}^{+}+\mathrm{H}_{2} \mathrm{SiO}_{4}^{2-}=\mathrm{CaH}_{3} \mathrm{SiO}_{4}^{+}$ & 14.4 \\
\hline $\mathrm{Ca}^{2+}+2 \mathrm{H}^{+}+2 \mathrm{H}_{2} \mathrm{SiO}_{4}^{2-}=\mathrm{Ca}\left(\mathrm{H}_{3} \mathrm{SiO}_{4}\right)_{2}^{0}$ & 35.6 \\
\hline $\mathrm{Ca}^{2+}+\mathrm{MoO}_{4}^{2-}=\mathrm{CaMoO}_{4}^{0}$ & 2.6 \\
\hline $\mathrm{Ca}^{2+}+\mathrm{H}_{2} \mathrm{O}=\mathrm{C} \dot{\mathrm{O}} \mathrm{OH}^{+}+\mathrm{H}^{+}$ & -12.6 \\
\hline $\mathrm{Mg}^{2+}+\mathrm{CO}_{3}^{2-}=\mathrm{MgCO}_{3}^{0}$ & 2.9 \\
\hline $\mathrm{Mg}^{2+}+\mathrm{H}^{+}+\mathrm{CO}_{3}^{2-}=\mathrm{MgHCO}_{3}^{+}$ & 11.4 \\
\hline $\mathrm{Mg}^{2+}+\mathrm{SO}_{4}^{2-}=\mathrm{MgSO}_{4}^{0}$ & 2.2 \\
\hline $\mathrm{Mg}^{2+}+\mathrm{F}^{-}=\mathrm{MgF}^{+}$ & 1.8 \\
\hline $\mathrm{Mg}^{2+}+\mathrm{H}^{+}+\mathrm{H}_{2} \mathrm{SiO}_{4}^{2-}=\mathrm{MgH}_{3} \mathrm{SiO}_{4}^{+}$ & 14.6 \\
\hline $\mathrm{Mg}^{2+}+2 \mathrm{H}^{+}+2 \mathrm{H}_{2} \mathrm{SiO}_{4}^{2-}=\mathrm{Mg}\left(\mathrm{H}_{3} \mathrm{SiO}_{4}\right)_{2}^{0}$ & 31.6 \\
\hline $\mathrm{Mg}^{2+}+\mathrm{MoO}_{4}^{2-}=\mathrm{MgMOO}_{4}^{0}$ & 3.0 \\
\hline $\mathrm{Mg}^{2+}+\mathrm{H}_{2} \mathrm{O}=\mathrm{MgOH}^{+}+\mathrm{H}^{+}$ & -11.8 \\
\hline $\mathrm{K}^{+}+\mathrm{CO}_{3}^{2-}=\mathrm{KCO}_{3}^{-}$ & 0.6 \\
\hline $\mathrm{K}^{+}+\mathrm{SO}_{4}^{2-}=\mathrm{KSO}_{4}^{-}$ & 0.9 \\
\hline $2 \mathrm{~K}^{+}+\mathrm{SO}_{4}^{2-}=\mathrm{K}_{2} \mathrm{SO}_{4}^{0-}$ & 1.5 \\
\hline $\mathrm{K}^{+}+\mathrm{F}^{-}=\mathrm{KF}^{0}$ & -0.8 \\
\hline $\mathrm{Na}^{+}+\mathrm{CO}_{3}^{2-}=\mathrm{NaCO}_{3}^{-}$ & 0.6 \\
\hline $\mathrm{Na}^{+}+\mathrm{SO}_{4}^{2-}=\mathrm{NaSO}_{4}^{-}$ & 1.1 \\
\hline $2 \mathrm{Na}^{+}+\mathrm{SO}_{4}^{2-}=\mathrm{Na}_{2} \mathrm{SO}_{4}^{0}$ & 1.5 \\
\hline $\mathrm{Na}^{+}+\mathrm{F}^{-}=\mathrm{NaF}^{0}$ & -1.0 \\
\hline $\mathrm{Na}^{+}+\mathrm{MOO}_{4}^{2-}=\mathrm{NaMOO}_{4}^{-}$ & 1.1 \\
\hline $\mathrm{Na}^{+}+\mathrm{H}_{2} \mathrm{O} \quad \mathrm{NaOH}^{0}+\mathrm{H}^{+}$ & -14.2 \\
\hline $\mathrm{H}^{+}+\mathrm{CO}_{3}^{2-}=\mathrm{HCO}_{3}^{-}$ & $10 \cdot 3$ \\
\hline $\mathrm{H}^{+}+\mathrm{H}_{2} \mathrm{SiO}_{4}^{2-}=\mathrm{H}_{3} \mathrm{SiO}_{4}^{-}$ & 13.3 \\
\hline $\mathrm{H}_{2} \mathrm{SiO}_{4}^{2-}=\mathrm{HSiO}_{4}^{3-}+\mathrm{H}^{+}$ & -9.9 \\
\hline $\mathrm{H}_{2} \mathrm{SiO}_{4}^{2-}=\mathrm{SiO}_{4}^{4-}+2 \mathrm{H}^{+}$ & -23.0 \\
\hline
\end{tabular}

a only significant complexes are listed here. 
Table 3. Mineralogy of Nonweathered and Weathered Processed oil shale Samples

\begin{tabular}{|c|c|c|c|c|}
\hline \multirow[b]{2}{*}{ Mineral } & \multicolumn{4}{|c|}{ Weathering Cycle } \\
\hline & Nonweathered. & 1 & 4 & 7 \\
\hline & \multicolumn{4}{|c|}{ Peak Intensity } \\
\hline & \multicolumn{3}{|c|}{ Combustec Western oil } & shale \\
\hline Anhydrite & $\mathbf{M}$ & 0 & 0 & 0 \\
\hline Ankeritic Dolomile & $\mathbf{W}$ & $\mathbf{W}$ & $\mathbf{W}$ & $\mathbf{W}$ \\
\hline Calcite & $\mathbf{W}$ & $\mathbf{M}$ & $\mathbf{s}$ & $\mathbf{s}$ \\
\hline Ettringite & 0 & $\mathbf{M}$ & 0 & 0 \\
\hline Gypsum & 0 & 0 & 0 & VW \\
\hline Hematite & VW & VW & VW & $\mathbf{W}$ \\
\hline Lime & $M$ & 0 & 0 & 0 \\
\hline Na-plagioclase & $\mathbf{M}$ & $\mathrm{w}$ & $\mathbf{M}$ & $\mathbf{M}$ \\
\hline Periclase & $\mathbf{W}$ & $\mathrm{VW}$ & 0 & 0 \\
\hline \multirow[t]{2}{*}{ Quartz } & vS & VS & VS & vS \\
\hline & \multicolumn{4}{|c|}{ Lu::gi-Ruhrgas } \\
\hline Analcime/Wairakite & $W$ & $W$ & $\mathbf{w}$ & $\mathbf{W}$ \\
\hline Anhydrite & VW & 0 & 0 & 0 \\
\hline Ankeritic Dulomite & $\mathbf{M}$ & $\mathbf{M}$ & $\mathbf{M}$ & $\mathbf{M}$ \\
\hline Calcite & $\mathbf{s}$ & vs & vs & Vs \\
\hline Ettringite & 0 & vw & 0 & 0 \\
\hline Hematite & VW & VW & viv & $\mathrm{vw}$ \\
\hline Na-plagioclase & $\mathbf{W}$ & $\mathbf{w}$ & $\mathbf{w}$ & $\mathbf{W}$ \\
\hline Periclase & $\mathrm{W}$ & 0 & 0 & 0 \\
\hline \multirow[t]{2}{*}{ Quartz } & vs & $\mathbf{s}$ & $\mathbf{s}$ & 3 \\
\hline & \multicolumn{2}{|c|}{ Combusted Eastern } & \multicolumn{2}{|c|}{ Oil shale } \\
\hline Gypsum & 0 & VW & VW & VW \\
\hline Hematite & $\mathrm{W}$ & $\mathrm{W}$ & $\mathrm{W}$ & $\mathbf{W}$ \\
\hline Illite & $\mathbf{W}$ & $\mathbf{w}$ & W & $\mathbf{W}$ \\
\hline Orthoclase & VW & VW & VW & $v w$ \\
\hline Quartz & vs & vs & Vs & Vs \\
\hline
\end{tabular}

Relative peak intensities: $V S=1008, \quad S=99-508, M=49-208, W=19-$ 108, $\mathrm{VW}<108,0=$ none detected. 
The mineral assemblage in the $\mathrm{CW}$ sample is similar to assemblages in Green River Formation oil shale samples retorted and combusted under similar conditions. For combustion temperatures ranging from 600 to $800^{\circ} \mathrm{C}\left(1112\right.$ to $\left.1472^{\circ} \mathrm{F}\right)$, minerals identified in processed Green River Formation oil shale samples include quartz, calcite, periclase, dolomite, analcime (wairakite), akermanite (gehlenite), augite, diopside, pyrite, pyrrhotite, lime, anhydrite, hematite, and feldspars (Park et al. 1979; Mason et al. 1984; Smith et al. 1978; Campbell and Burnham 1978; Williamson et al. 1980). Akermanite, augite, analcime, pyrite, pyrrhotite, and diopside were not retected in the CW sample.

During the first weathering cycle, lime and anhydrite dissolved, and the solubilized $\mathrm{Ca}$ and $\mathrm{SO}_{4}$ precipitated as calcite and a Ca-rich, Alpoor ettringite, $\mathrm{Ca}_{6} .32 \mathrm{Al}_{1.05}\left(\mathrm{SO}_{4}\right)_{2.27}\left(\mathrm{SiO}_{4}\right)_{0.36}(\mathrm{OH})_{9.83} \cdot 26 \mathrm{H}_{2} \mathrm{O}$ (Essington 1990b). A decrease in periclase XRD peak intensities was also apparent. As weathering increased, ettringite and periclase dissolved. Calcium and $\mathrm{SO}_{4}$, solubilized by the dissolution of ettringite, precipitated as calcite and gyprum.

An XRD-detectable, Mg-bearing mineral did not form during $C W$ weathering. Reddy and Lindsay (1986) and Reddy et al. (1986) examined the leachate chemistry and mineralogy of a processed and a recarbonated processed Green River Formation oil shale and found that Mg activities in spent oil shale leachates were controlled by Mg-silicates (clinoenstatite and diopside before recarbonation, and antigorite after). They further report that XRD results substantiated the occurrence of these minerals. In the present study, the occurrence of clinoenstatite, diopside, or antigorite in the nonweathered and weathered CW samples could not be resolved because the XRD peaks used to identify these Mg silicates coincided with those of calcite, plagioclase, gypsum, and ankeritic dolomite.

The mineralogy of the LR processed oil shale, also produced from Green River Formation oil shale, was similar to that of the $\mathrm{CW}$ sample (Table 3). However, it is apparent that the LR process temperature was lower than that used to produce the $\mathrm{CW}$ sample, resulting in a slightly different mineral assemblage. process temperatures were not sufficient to produce detectable quantities of lime or decompose analcime. Further, the IR sample contained lesser amounts of periclase and anhydrite and greater amounts of calcite compared with the CW sample. This observation is consistent with lower combustion temperatures. However, the process temperature was sufficient to produce XRDdetectable hematite from pyrite and ankeritic dolomite.

The weathering reactions of the LR sample were also similar to those of the $C W$ sample (Table 3). During the first weathering cycle, periclase and anhydrite dissolved, and solubilized Ca and $\mathrm{SC}_{4}$ precipitated as ettringite and calcite. Mg-bearing minerals were not detected in the weathered LR samples. With additional weathering, ettringite dissolved, and solubilized Ca precipitated as calcite.

The mineralogy of the combusted New Albany shale sample (CE) is similar to that of the raw oil shale (Tables 1 and 3 ). Pyrite is 
thermally altered to hematite (Smith et al. 1978; williamson et al. 1980). Gypsum was the only weathering product detected by XRD during the weathering study. With the exception of gypsum, the remaining mineral assemblage was not altered during the weathering study. The appearance of gypsum in processed eastern oil shale weathered in field lysimeters has been predicted from solubility data (Essington 1989b; Robl 1989). Thus, the occurrence in the laboratory-weathered samples substantiates the presence of gypsum in a field disposal environment.

\section{Leachate Chemistry}

Figure 1 illustrates the changes in processed oil shale leachate pH and EC as a function of weathering cycle. The high alkalinity of $\mathrm{CW}$ and LR samples, pr marily resulting from the dissolution of lime and periclase, was mobile and readily leached during the initial weathering cycles. After five weathering cycles, $C W$ and LR leachate $p H$ values stabilize between 8.5 and 9 , suggesting that calcite influenced leachate of $\mathrm{pH}$. The reduction in leachate $\mathrm{pH}$ for spent Green River Formation oil shale leachate has been observed in field lysimeters (Garland et al. 1979; Richardson et al. 1981; Stark and Redente 1986). Garland et al. (1979) suggest that the reduction in leachate $\mathrm{pH}$ was due to oxidation of rediced sulfur species, and to a lesser extent, recarbonation (absorption of $\mathrm{CO}_{2}$ ). Reddy et al. (1986) viewed recarbonation as the dominant process responsible for the reduction in spent oil shale leachat.e alkalinity. Because reduced sulfur species were not detected in the humidity cell leachates, the reduction of $\mathrm{CW}$ and $\mathrm{LR}$ leachate $\mathrm{pH}$ values probably resulted from the combined effects of recarbonation and leaching.

The $\mathrm{pH}$ of processed eastern oil shale leachates is dependent on the pyrite content of the solid waste product, which in turn is dependent on oil shale processing parameters (heating rate and maximum temperature) (Williamson et al. 1980; Cisler and Koppenal 1982; Paciorek et al. 1983; Tian and Ehmann 1984). Acidic spent oil shale leachates are produced when the oil extraction process does not thermally decompose pyrite. The $\mathrm{pH}$ values of $\mathrm{CE}$ leachates tended to fluctuate between 7.5 and 8.5 during this study. This shows that the combustion process was sufficient to decompose pyrite (to hematite) and neutralize the acid production potential of the waste material.

The humidity cell leachate results for the CE sample were different from those reported by sullivan et al. (1987c) for retorted and combusted New Albany shale. The $\mathrm{pH}$ of the $\mathrm{CE}$ materials was constant during the weathering study, even though the material had a negative acid-neutralizing capacity ( $\mathrm{CE}$ acid-base account of -2.3 ton $\mathrm{CaCO}_{3} / 1000$ ton of spent oil shale, unpublished data, M.E. Essington). Sullivan et al. (1987c) noted a continual decrease in leachate pH through 20 weathering cycles. Final leachate $\mathrm{pH}$ values of approximately 2.5 and 5 were achieved for the retorted and combusted New Albany Shale samples, respectively, even though the New Albany shale combustion process used lime as an additive that resulted in an acid base account of +224.7 ton $\mathrm{CaCO}_{3} / 10 \mathrm{CO}$ ton waste. 

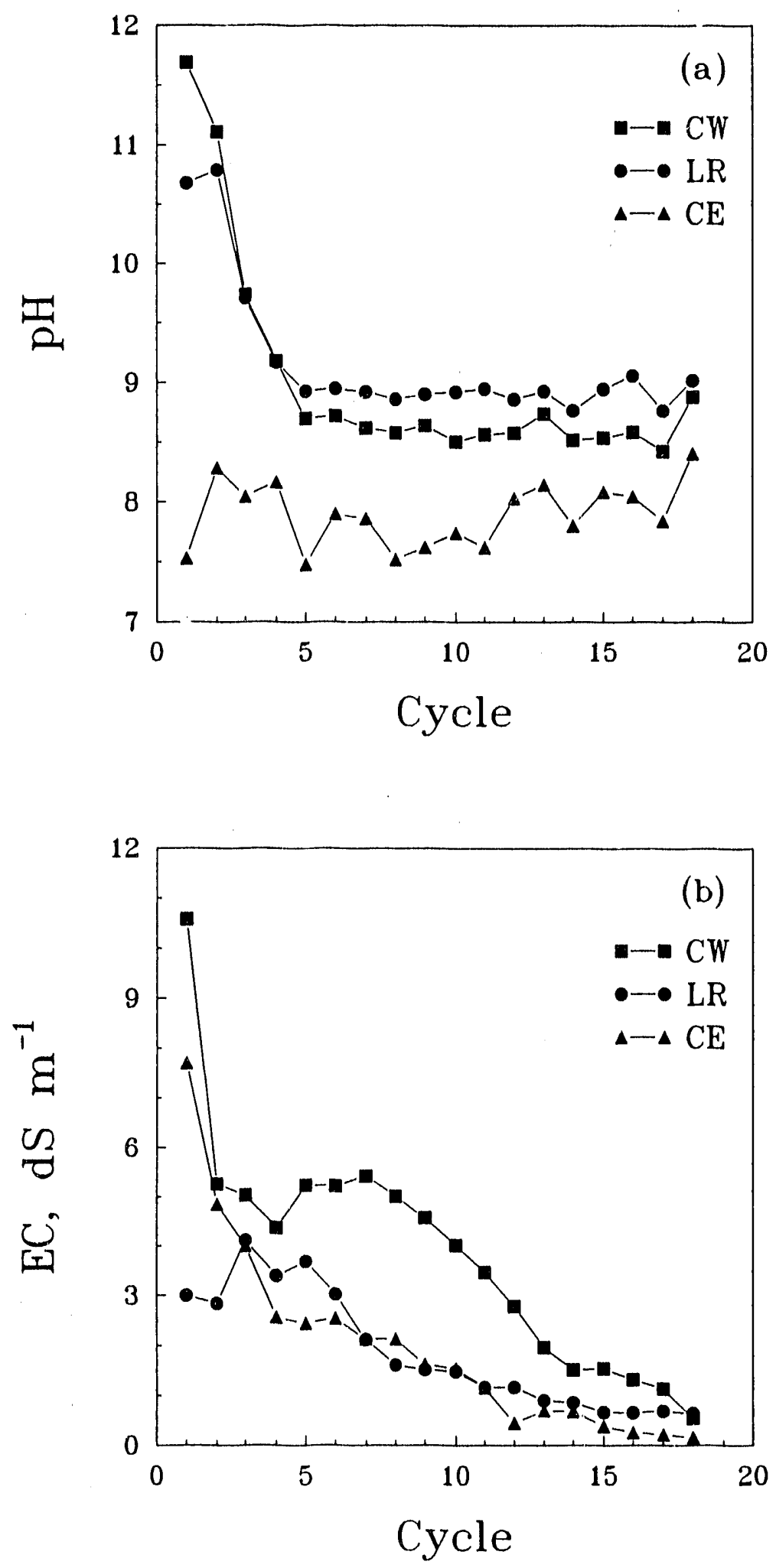

Figure 1. pH (a) and EC (b) of Humidity Cell Leachates from Combusted (CW) and Lurgi-Ruhrgas Processed (LR) Green River Formation Oil Shale and Combusted New Albany Shale (CE) 
Soluble salts in processed oil shale are readily removed with leaching (Fransway and Wagenet 1981; stollenwerk and Runnel1s 1981; Stark and Redente 1986). A general decrease in salt content, determined by EC measurements, was also observed for the CW, LR, and CE processed oil shale leachates. Leachates from the initial weathering cycle of $\mathrm{CW}$ and $C E$ were highly saline in comparison with the salinity of the initial LR leachates. Following the first weathering cycle and the removal of the highly soluble salts, the EC of the CW leachates remained constant through the sixth weathering cycle and then a general decreasing trend was observed. For the CE samples, leachate EC consistently decreased with weathering. The EC of the LR leachates also remained relatively constant through the sixih weathering cycle, before a consistent decrease was observed. Reduction of leachate EC to $<2 \mathrm{dS} \mathrm{m}^{-1}$ required 13 weathering cycles for $C E, 8$ cycles for $L R$, and 9 cycles for $C E$.

Initially, relatively low solubilities of $\mathrm{Mg}, \mathrm{Ca}, \mathrm{Sr}, \mathrm{Li}$, and $\mathrm{B}$ were measured in the $\mathrm{CW}$ leachates (Figure 2). Depressed concentrations of these constituents may be due to the slow kinetics of dissolution or to the relative stability of the solid phases (lime and periclase) under the highly alkaline conditions. As alkalinity was removed (or neutralized by $\mathrm{CO}_{2}$ absorption) and $\mathrm{pH}$ decreased, the potential for oxide dissolution increased, resulting in higher concentrations of these elements. As leaching continued, leachate concentrations decreased. Relatively low initial $\mathrm{CO}_{3}$ concentrations were measured. $\mathrm{High}$ alkalinity and an abundance of soluble ca resulted in the precipitation of absorbed $\mathrm{CO}_{2}$. As $\mathrm{pH}$ and soluble Ca decreased, $\mathrm{CO}_{3}$ concentrations increased and stabilized, as influenced by calcite solubility.

For the remaining parameters $\mathrm{SO}_{4}, \mathrm{Na}, \mathrm{K}, \mathrm{Cl}, \mathrm{si}, \mathrm{F}$, and Mo, the highest $C W$ leachate concentrations occurred in the initial extracts. Leachate concentrations of these constituents generally decreased with the number of weathering cycles. The behavior of $M O, B$, and $F$ in $C W$ and IR materials during weathering is similar to that observed by stollenwerk and Runnells (1981). The leachate concentracions of Mo rapidly decreased with leaching. The leachate concentrations of $F$ and $B$ were reduced with leaching. However, $F$ corcentrations remained relatively high.

Leachates from the IR samples were less alkaline initially than those of $\mathrm{CW}$, because the concentrations of alkaline earth oxides were lower. For $\mathrm{Ca}, \mathrm{Sr}$, and $\mathrm{B}$, the relatively low initial concentrations observed in CW leachates were not detected in the LR leachates (Figure 3). However, in LR leachates $\mathrm{Mg}$, $\mathrm{Li}$, and $\mathrm{CO}_{3}$ concentrations responded to weathering in a fashion similar to those species in the $\mathrm{CW}$ leachates.

In relation to XRD mineralogy, initially high $p H$ values for the $C W$ and LR samples were due to the dissolution of lime and periclase. Constituents released from the dissolution of these and other soluble minerals, such as $\mathrm{Ca}, \mathrm{Al}\left(0.53\right.$ and $0.40 \mathrm{mmol} \mathrm{L}^{-1}$ in cycle 1 and 2 leachates, respectively), and $\mathrm{SO}_{4}$ reprecipitated as ettringite, which is stable under the highly alkaline conditions (Essington 1990a). As the alkalinity was leached from the samples, ettringite became unstable, and the solubilized $\mathrm{Ca}$ and $\mathrm{SO}_{4}$ precipitated as calcite and gypsum. The 

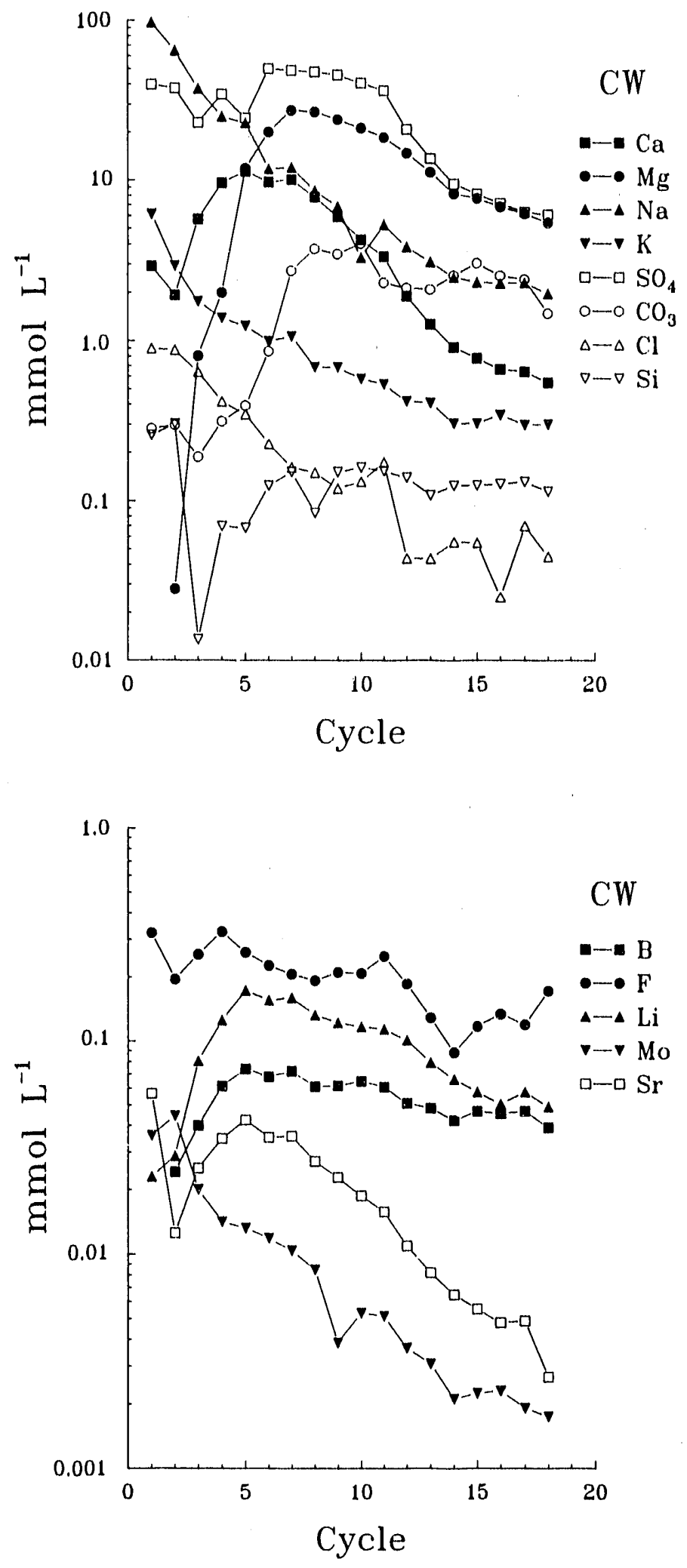

Figure 2. Chemical Characteristics of Humidity Cell Leachates from Combusted Green River Formation oil shale 

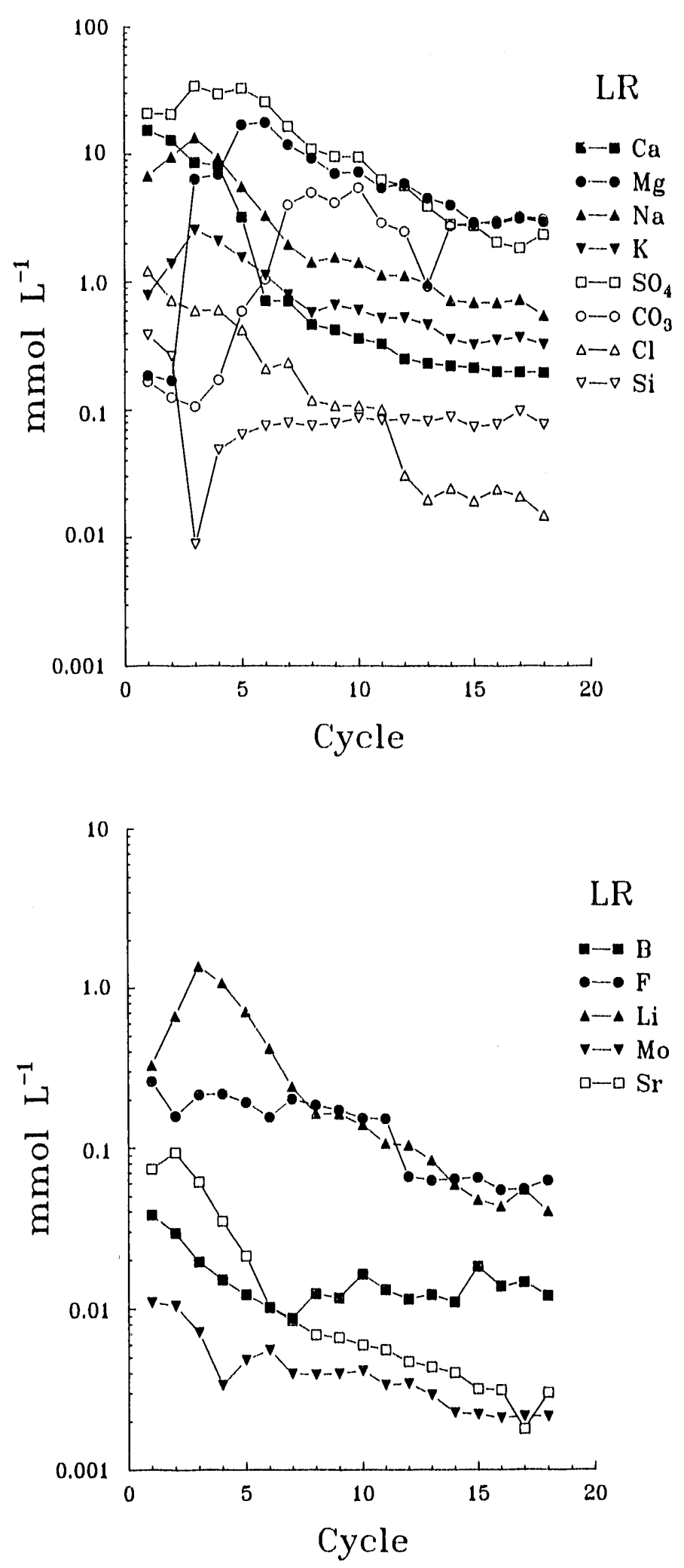

Figure 3. Chemical Characteristics of Humidity Cell Leachates from Lurgi-Ruhrgas Processed Green River Formation Oil Shale 
dissolution of these minerals then controlled the leachate concentrations of $\mathrm{Ca}$ and $\mathrm{SO}_{4}$. Under the highly alkaline conditions, $\mathrm{CO}_{2}$ is absorbed and rapidly precipitates as calcite (Reddy et al. 1986). As leaching increased and $\mathrm{pH}$ was reduced, $\mathrm{CO}_{3}$ concentrations leveled off and were controlled by calcite. Magnesium released by the dissoiution of periclase did not appear to reprecipitate as predicted by Reddy et al. (1986) and Reddy and Lindsay (1986). The released Mg remained soluble and was leached from the processed oil shale. The concentrations of the highly soluble salts, $\mathrm{Na}, \mathrm{SO}_{4}$, and $\mathrm{K}$, diminished with weathering cycles.

With increased weathering, the $\mathrm{CE}$ leachate concentrations of soluble consituents generally decreased (Figure 4). Further, leachate concentrations of $\mathrm{Si}$ increased and $\mathrm{CO}_{3}$ leachate concentrations remained relatively constant with weathering. Leachate concentrations of Mo and $B$ were initially elevated compared with the CW and IR leachates. However, the $C E$ leachate concentrations of these elements and $F$ rapidly decreased with weathering. The conversion of pyrite to hematite during the combustion process has eliminated the acid drainage potential of the processed New Albany Shale.

\section{Batch Equilibrium Solubility Relationships}

The use of chemical thermodynamics to describe the status of an environment has been practiced for a number of years. In a natural or waste affected environment, the number of reactions that must be considered to characterize solution-phase and solid-phase chemistry can be quite large (Baham 1984). Efforts to account for these many reactions have resulted in the development of computer equilibrium models (or codes). These geochemical codes, which have been extensively reviewed and compared (Nordstrom et al. 1979; Baham 1984; Spusito 1984). consider many of the attributes desirable in a geochemical code (Jenne 1979; Mattigod et al. 1981; Mattigod and Page 1983). The codes use jon association constants, solubility product constants, and analytical concentration data to predict the distribution of an element between free anionic or cationic species and ion pairs and solid phases. Although the ion association model has a firm theoretical basis, the computer codes used to perform the model computations have a number of inherent shortcomings. Principal among these are incomplete data on solubility-controlling solids, such as stoichiometry, crystallinity, and thermodynamic properties; inability to describe thermodynamically adsorption/desorption and ion exchange reactions; lack of thermodynamic data to characterize ion pair and complex ion formation reaction involving metal ions and organic ligands; lack of accurate thermodynamic data for reduction-oxidation reactions; and variations in the thermodynamic data sets used by the different geochemical computer codes (Jenne 1979).

The ion association model can be used to indirectly identify solid phases that control leachate chemistry. The method consists of comparing the predicted ion activity products (IAP) in spent oil shale solutions with the solubility product constants ( $K_{s p}$ ) for various 

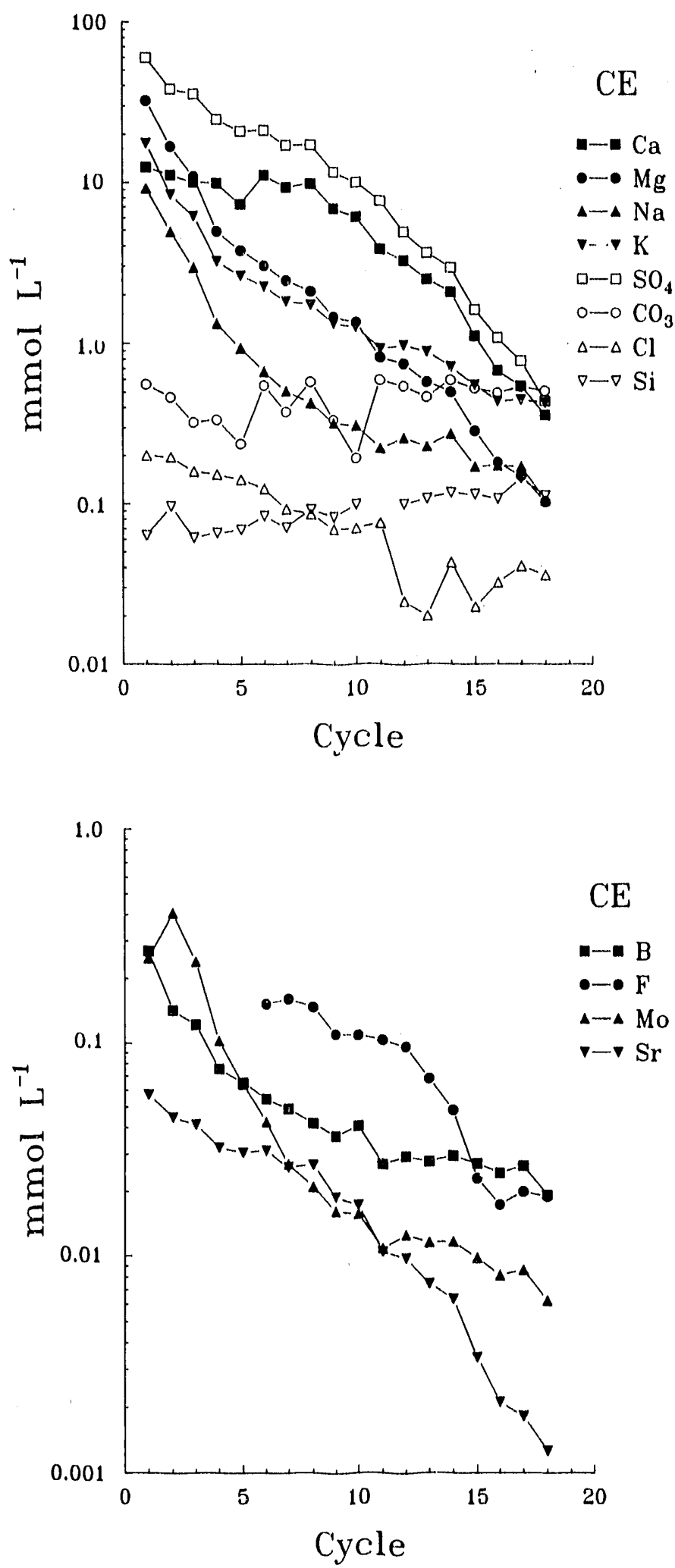

Figure 4. Chemical Characteristics of Humidity Cell Leachates from Combusted New Albany Shale 
minerals. Assuming equilibrium exists, the mineral whose $\mathrm{K}_{\mathrm{gp}}$ is equal to the predicted IAP is assumed to be present and controlifing ionic activities in the spent oil shale solution. Basic requirements for obtaining valid results from the application of the equilibrium solubility method are (1) the condition of equilibrium between mineral and aqueous components; (2) all minerals that are likely to be present must be considered, and their $\mathrm{K}_{\mathrm{sp}}$ vaiues must be known; (3) unit activity of the mineral phases; (4) accurate computation of ion activities and IAP vallies; and (5) knowledge regarding the kinetics of the various mineral dissolution and precipitation reactions (Mattigod of al. 1981). The squilibrium solubility method has been extensively applied to indirectly identify mineral phases that may control spent oil shale solution chemistry (Saether and Runnells 1980; Stollenwerk and Runnells 1981; Essington and Spackman 1986 and 1988; Reddy and Lindsay 1986; Reddy et al. 1986; Essington et al. 1987; Essington 1987; Reddy and Hasfurther 1989; Reddy et al. 1989; Essington 1990a).

The powellite IAP values predicted using GEOCHEM for spent western oil shale data found in the literature are highly variable, particularly at short reaction times (Figure 5). In general, leachates from spent western oil shale are undersaturated with respect to powellite. However, at short reaction times, a number of solutions approach saturation with respect to powellite. Comparable powellite IAP and $\mathrm{K}_{\mathrm{sp}} \mathrm{values}$ at these short reaction times has been used as indirect evidence that powellite is present and controlling Mo concentrations (Reddy and Hasfurther 1989). However, Essington (1990b) noted that a reaction time of 28 days is required to attain powellite solubility equilibrium in $\mathrm{KNO}_{3}$ solutions. As reaction times increase, spent oil shale leachates become increasingly undersaturated with respect to powellite. This suggests that Mo concentrations are not controlled by powellite solubility.

The fluorite IAP values are also highly variable, particularly at short reaction times (Figure 6 ). In general, the batch solutions are supersaturated with respect to fluorite at short reaction times. As equilibration times increase, the spent oil shale solutions approach saturation with respect to fluorite. These data are indirect evidence that $f$ in spent western oil shale may reside in fluorite and also show that soluble $F$ equilibrium with fluorite may require long equilibration times. The scattering associated with the powellite and fluorite IAP values can be attributed to the many different process parameters used in the procluction of the spent oil shale samples. Process heating rate, maximum temperature and duration, and gas composition will directly influence the mineralogical composition of the spent oil shale (Campbell and Burnham 1978; Park et al. 1979; Williamson et al. 1980), which in turn influences leachate composition. The spent oil shales examined (Figures 5 and 6 ) were generated using a paraho (indirect and direct retort) or a combustion process (fluidized-bed, TOSCO, Lurgi-Ruhrgas), which produce solid waste materials having similar mineralogical and chemical character. 


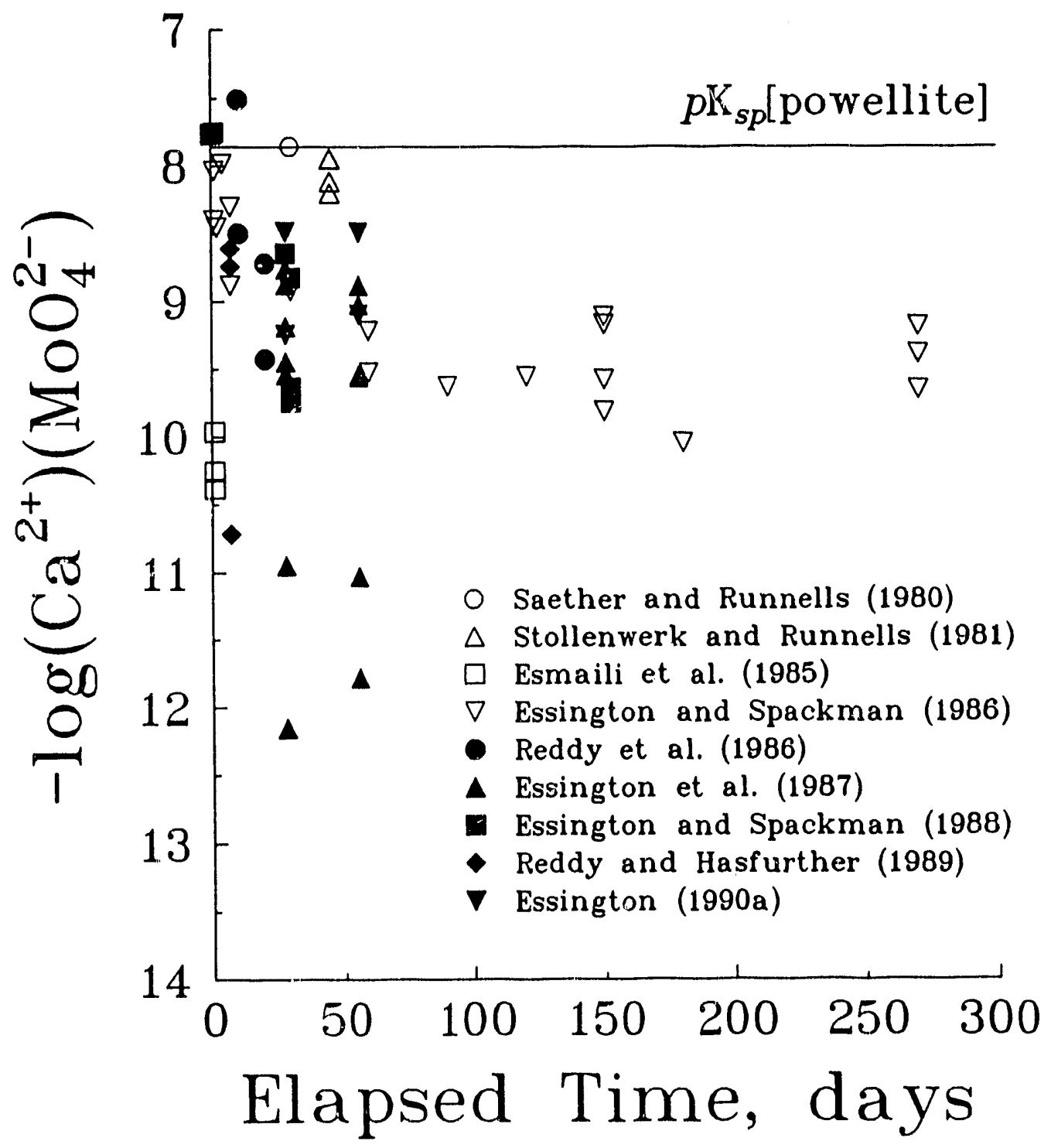

Figure 5. Poweilite Ion Activity Product values as a Function of Elapsed Time 


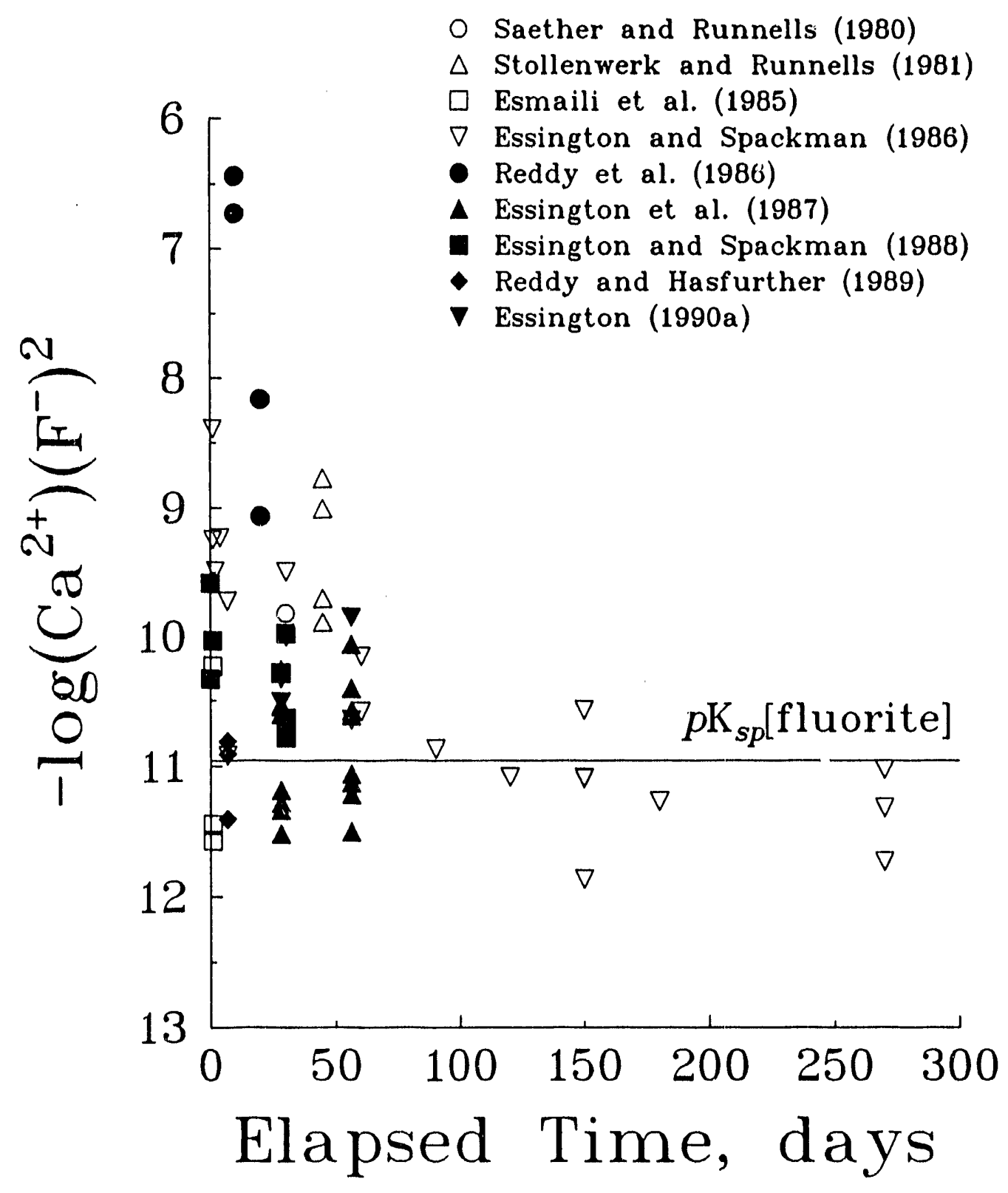

Figure 6. Fluorite Ion Activity Product Values as a Function of Elapsed Time 


\section{Simulated Equilibrium Weathering}

Processed oil shale leachate $\mathrm{pH}, \mathrm{EC}$, and elemental composition are listed in Table 4 as a function of the weathering cycle. These results are similar to those reported above for the nonequilibrium weathering of CW and LR samples. Leachates from the LR samples are initially less alkaline than those of $\mathrm{CW}$, which have a higher alkaline earth oxide content. A general decrease in salt content, determined by EC measurements, is also detected in the processed oil shale leachates. Initially, the leachates have relatively low concentrations of $\mathrm{Mg}$ and $\mathrm{Ca}$. The depressed concentrations of these elements may be due to the slow kinetics of dissolution, or to the relative stability of the solid phases (lime and periclase) under the highly alkaline conditions. As alkalinity is removed or neutralized and $\mathrm{pH}$ decreases, the potential for. oxide dissolution increases, resulting in increased concentrations of these elements.

The highest leachate concentrations for $\mathrm{so}_{4}, \mathrm{CO}_{3}, \mathrm{Na}, \mathrm{K}, \mathrm{Cl}$, and $\mathrm{si}$ were in the initial extracts. Leachate concentrations of these elements generally decreased with the number of weathering cycles. The concentration of Mo in $C W$ and LR leachates also decreased with leaching. Leachate concentrations of $F$ were reduced with leaching; however, $F$ concentrations remain relatively high, particularly in the $\mathrm{CW}$ sample. During the initial weathering cycle the spent oil shale leachates were undersaturated with respect to powellite (Figure 7 ). The second cycle and remaining LR leachates were saturated with respect to powellite. The $\mathrm{CW}$ leachates approached saturation with respect to powellite during cycles 5 and 6 . These results suggest that powellite will control Mo chemistry in spent oil shale leachates as equilibrium weathering proceeds. Thus, the prediction of Mo fate and behavior in a weathering spent oil shale environment can be accomplished using equilibrium models.

The spent oil shale leachates approached near-saturation with respect to fluorite during the initial weathering cycles (Figure 8 ). However, as equilibrium weathering continued, the leachates become supersaturated with respect to fluorite. These results suggest that fluorite is not controlling the concentration of $F$ in the spent oil shale leachates. The results further suggest that the $F$ released during the weathering of spent oil shale may be leached to potentially affect groundwater environments. These results also show that the prediction of $F$ chemistry in a spent oil shale disposal environment can not be based on fluorite solubility relationships. The supersaturated conditions show that there is a potential for fluorite to precipitate. However, kinetic constraints may limit fluorite precipitation.

The interpretation of spent oil shale solubility results will depend upon the method used to obtain equilibrium leachates. The results of the equilibrium studies show that the batch results are comparable to those obtained for the initial cycle of the simulated equilibrium weathering study. Spent oil shale batch equilibrium extracts were undersaturated with respect to powellite and saturated with respect to fluorite. 


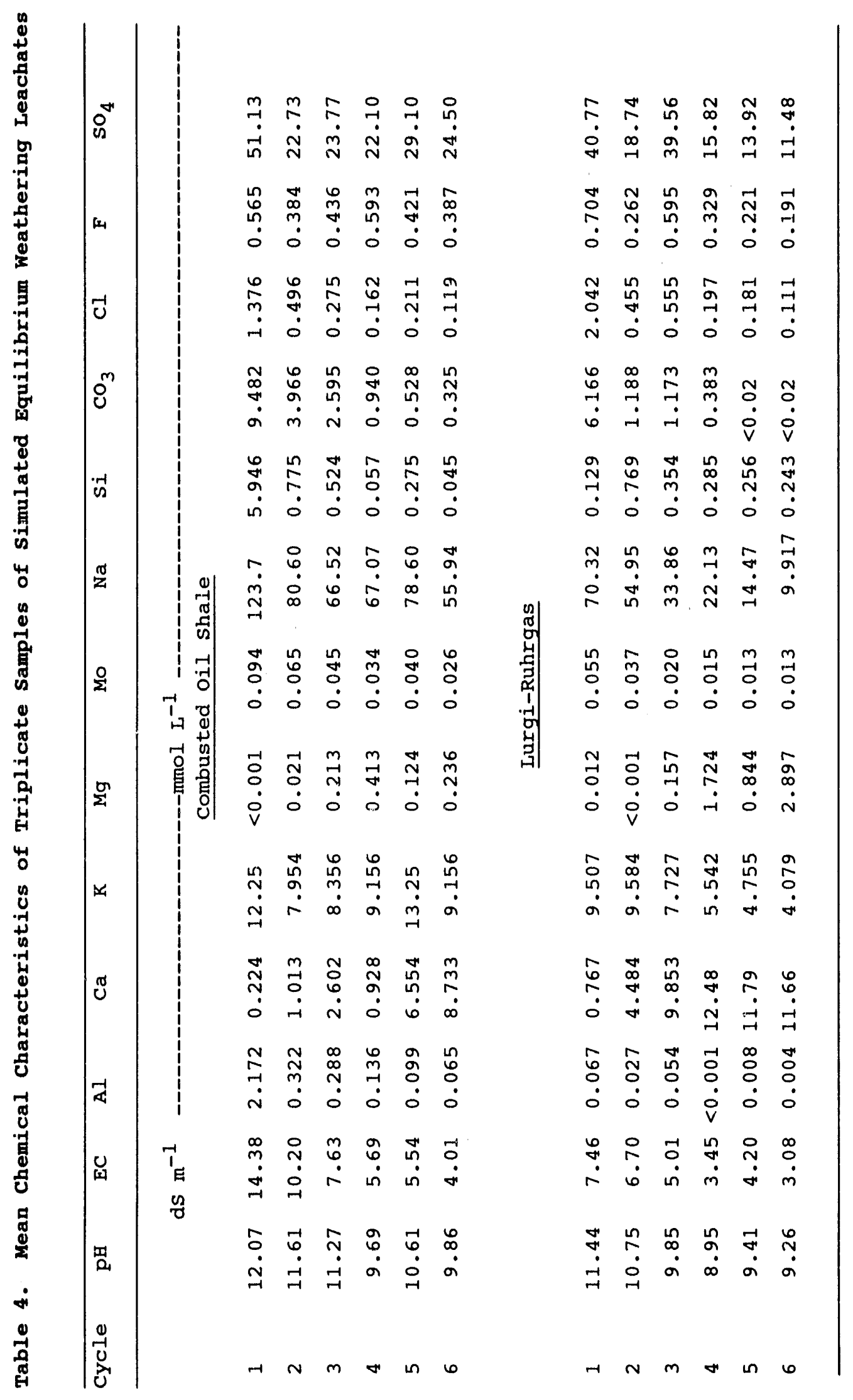




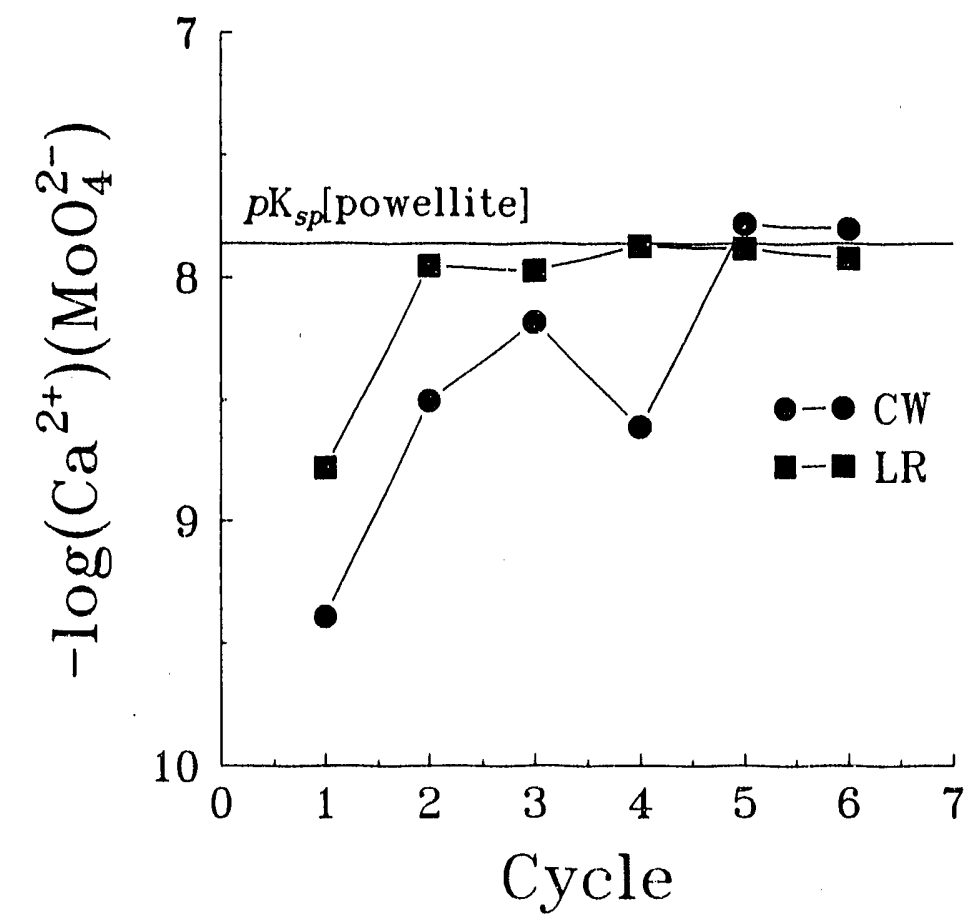

3 Sure 7. Powellite Ion Activity Product Values as a Function of Weathering Cycle

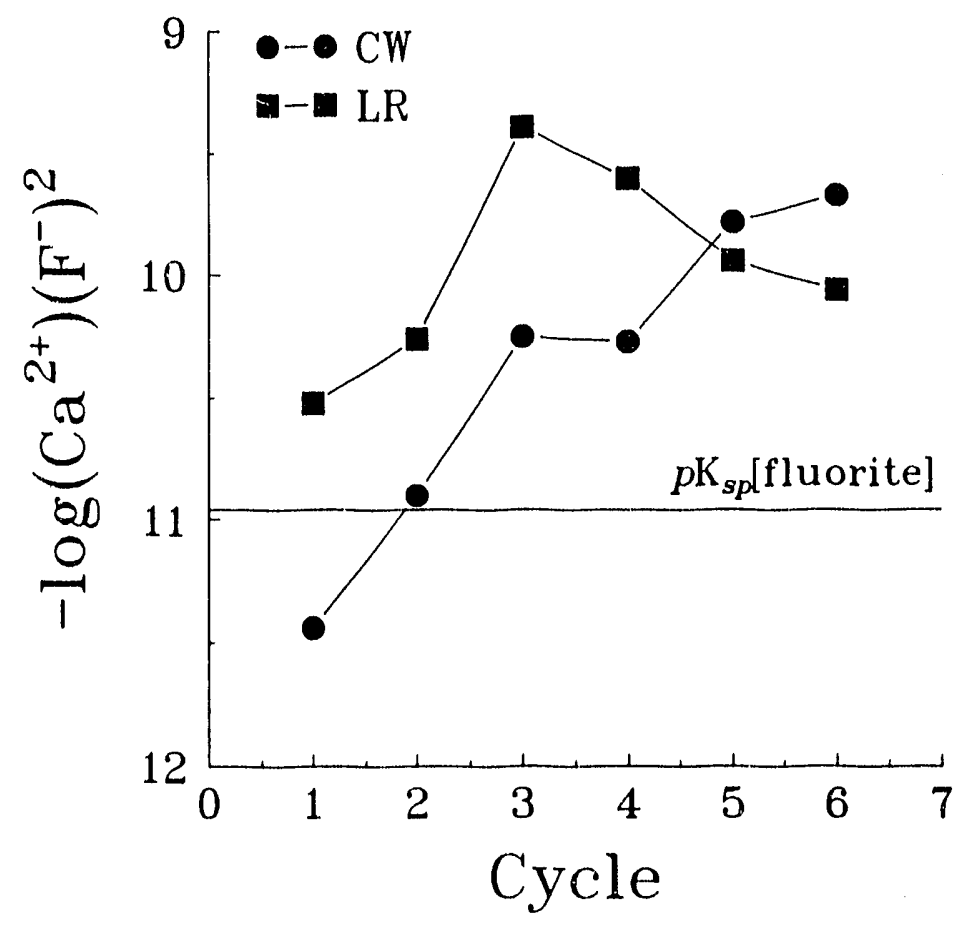

Figure 8. Fluorite Ion Activity Product Values as a Function of Weatharing cycle 


\section{CONCLUSIONS}

The mineralogy of western spent oil shales will change with time. Leachate $\mathrm{pH}$ will rapidly decrease from highly alkaline values to $\mathrm{pH}$ values controlled by calcite. The leachate concentrations of soluble salts will also decrease. During the initial stages of weathering, the processed western oil shale leachates were dominated by Na, hydroxide, and $\mathrm{SO}_{4}$. As weathering continued, $\mathrm{Mg}, \mathrm{SO}_{4}$, and $\mathrm{CO}_{3}$ dominated leachate chemistry. Boron should not pose an environmental hazard because leachate concentrations remained low and did not exceed 0.1 mmol $\mathrm{L}^{-1}$. Concentrations of Mo will he elevated initially but will decrease with increased leaching. However, concentrations of $F$ will remain elevated.

The weathering results suggest that alkalinity, salinity, and potentially problematic elements may be readily leached from the $C W$ and IR samples. However, the minimal annual precipitation at potential disposal sites will not allow weathering to proceed. Thus, the leachate chemistry and mineralogy of the spent oil shale materials in the disposal environment will be closely associated with that observed in the initial weathering cycles. These data coupled with the disposal site hydrology also suggest that the potential for off-site contamination may be minimal. Effective revegetation may be accomplished with leaching.

For the CE sample, minor alterations in mineralogy occurred in the disposal environment, primarily the precipitation of gypsum. Potentially hazardous components (Mo, F, and B) will be rapidly removed to influence groundwater and surface water. Similarly, soluble salts will be rapidly removed. In general, $\mathrm{Ca}$ and $\mathrm{SO}_{4}$ dominate the chemistry of $\mathrm{CE}$ leachates. The $\mathrm{CE}$ samples will reach higher stages of weatherin? (i.e., a greater number of weathering cycles will oocur in the environment) compared with the processed western oil shale samples. This is because the eastern United states has a greater annual precipitation than does the western united states. The results do not suggest that the $C E$ sample is potentially problematic with respect to acid drainage.

GEOCHEM-predicted powellite and fluorite IAP values of spent western oil shale literature data are highly variabla. Spent western oil shale leachates are generally undersaturated with respect to powellite. However, in this study, some solutions approached saturation with respect to powellite at short reaction times. Reddy and Hasfurther (1989) determined that powellite was controlling Mo concentrations by comparing powellite IAP and $\mathrm{k}_{\mathrm{sp}}$ values. However, powellite solubility equilibrium in $\mathrm{KNO}_{3}$ solutions was noted by Essington (1990) to require a reaction time of 28 days.

This study determined that as reaction times increased, spent oil shale leachates became increasingly undersaturated with respect to powellite, therefore, suggesting that Mo concentrations are not controlled by powelitie solubility. Fluorite was generally supersaturated in the batch solutions at short reaction times. However, with increasing reaction time, the spent oil shale solutions approached saturation with respect to fiuorite. This evidence indirectiy infers 
that in spent western oil shale, $F$ concentrations may be controlled by fluorite. Also, these data suggest that long equilibration times may be needed for soluble $F$ to reach equilibrium with fluorite.

Based on these results, we can conclude that a F-bearing mineral in spent oil shale is fluorite. However, because a long equilibrium period is required, $F$ chemistry can not be predicted using solubility models. Similarly, as spent oil shales weather, F chemistry is not controlled by fluorite solubility. Mo concentrations in the batch equilibrations are undersaturated with respect to powellite, suggesting that this solid phase does not control Mo chemistry in fresh spent oil shale. As the spent oil shale weathers, Mo concentrations are apparently controlled by powellite solubility. Thus, the chemistry of Mo in spent oil shale disposal environments which are subject to the slow infiltration of water can be predicted using solubility relationships. 


\section{ACKNOWLEDGEMENTS}

This work was supported by the U.S. Department of Energy under Cooperative Agreement DE-FC21-86MC11076. Sincere thanks are also given to Nancy Niss and Brian Hart for analytical support.

\section{DISCLAIMER}

Mention of specific brand names or models of equipment is for information only and does not imply endorsement of any particular brand. 
Adriano, D.C., 1986, Trace Elements in the Terrestrial Environment. Springer-Verlag, New York, NY.

Albasel, N., and P.F. Pratt, 1989 , Guidelines for Molybdenum in Irrigation Waters. J. Environ. Qual., 18: 259-264.

Baham, J., 1984, Prediction of Ion Activities in soil solutions: Computer Equilibrium Modeling. Soil Sci. Soc. Am. J., 48: 525-531.

Campbel.1, J.H., and A.K. Burnham, 1978, Oil shale Retorting: Kinetics of the Decomposition of Carbonate Minerals and subsequent Reaction of $\mathrm{CO}_{2}$ with Char, in Gary, J.H., ed., 11 th oil shale symp. Proc., Colorado School of Mines Press, Golden, CO, 242-259.

Caruccio, F.T., 1968, An Evaluation of Factors Affecting Acid Mine Drainage Production and the Groundwater Interaction in selected Areas of Western Pennsylvania. Pap. Symp. Coal Mine Drain. Res., 2: $107-152$.

Cisler, K., and D.W. Koppenaal, 1982, Leaching studies on Kentucky Oil Shale Wastes: An Update. in 1982 Eastern Oil shale symp. Proc.. Institute for Mining and Minerals Research, Lexington, KY, 273-281.

Esmaili, E., R.B. Carroll, and L.P. Jackson, 1985, Assessing Potential Trace Metal Leachability of Retorted oil shale by Complexometric Agents, in Gary, J.H., ed., 18th oil shale symp. Proc., Colorado School of Mines Press, Golden, CO, 326-337.

Essington, M.E., 1987, Modeling Fluoride Chemistry in Hydrated and Recarbonated spent western oil shale, in Pettit, R., ed., 1987 Eastern oil Shale symp. Proc., Kentucky Energy Cabinet Laboratory, Lexington, KY, 21-33.

Essington, M.E., 1989a, Trace Element Mineral Transformations Associated with Hydration and Recarbonation of Retorted oil Shale. Environ. Geol. Water Sci., 13: 59-66.

Essington, M.E., 1989b, Chemical Equilibria Model Analysis of Hope Creek Eastern Oil Shale Lysimeter Leachate Data, in Lazar, D.J., ed., 1989 Eastern oil shale symp. Proc., Institute for Mining and Minerals Research, Lexington, KY, 326-338.

Essington, M.E., 1990a, Calcium Mclybdate Solubility in spent oil shale and a Preliminary Evaluation of the Association Constants for the Formation of $\mathrm{CaMOO}_{4}{ }^{\mathrm{O}}(\mathrm{aq}), \mathrm{KMOO}_{4}{ }^{-}(\mathrm{aq})$, and $\mathrm{NaMOO}_{4}^{-}(\mathrm{aq})$. Environ. Sci. Technol., 24:214-220.

Essington, M.E., $1990 \mathrm{~b}$, The Composition and Solubility of Ettringite Precipitated from Combusted oil shale, in Gary, J.H., ed., 23rd oil Shale symp. proc., Colorado school of Mines Press, Golden, co. 
Essington, M.E., 1991, Formation of Calcium and Magnegium Molybdate Complexes in Dilute Aqueous solutions. Soil Sci. Soc. Am. J., in review.

Esaington, M.E., and R.B. Carroll, 1985, Extraction of Inorganic Chemical Constituents from Retorted oil shale by complexometric Agents. Laramie, WY, WRI Report to DOE, DOE/FE/60177-2152.

Essington, M.E., and I.K. Spackman, 1986, Recarbonation of Retorted oil Shale: the Influence on Mineralogy and Leachate chemistry. Laramie, WY, WRI Report to DOE, DOE/FE/60177-2433.

Essington, M.E., and L.K. Spackman, 1988, Inorganic Geochemical Investigations of spent Oil shale. Laramie, WY, WRI Report to DOE, $\mathrm{DOE} / \mathrm{MC} / 11.076-2701$.

Essington, M.E., and G.S. Huntington, 1990, Formation of Calcium and Magnesium Molybdate Complexes in Dilute Aqueous solutions and Evaluation of Powellite Solubility in spent oil shale. Laramie, WY, WRI Report to DOE, DOE/MC/11076-2851.

Essington, M.E., L.K. Spackman, J.D. Harbour, and K.D. Hartman, 1987, Physical and Chemical Characteristics of Retorted and Combusted Western Reference Oil shale. Laramie, WY, WRI Report to DOE, DOE/MC/11076-2453.

Fransway, D.F., and R.J. Wagenet, 1981, salt Release and Movement in Processed oil Shale. J. Environ. Qual., 10: 107-113.

Garland, T.R., R.E. Wildung, and H.P. Harbert, 1979, Influence of Irrigation and Weathering Reactions on the Composition of Percolates from Retorted oil shale in Field Lysimeters, in Gary, J.H., ed., 12 th oil shale symp. Proc., Colorado School of Mines Press, Golden, Co, 52-57.

Grant, C.I., F.J. Trujillo, H.E. Taylor, M.M. Miller, and R.K. skogerboe, 1981, Comparison of Laboratory Methods for studying Leaching of Retorted oil shale, in Graves, D.H., ed., 1981 symp. on surface Mining Hydrology, Sedimentology, and Reclamation, Univ. of Kentucky, Lexington, $\mathrm{KY}, 451-456$.

Jenne, E.A., 1979, Chemical Modeling--Goals, Problems, Approaches, and Priorities, in Jenne, E.A., ed., Chemical Modeling in Aqueous systems. Am. Chem. Soc. Symp. Ser. 93, Washington, DC, 3-24.

Jones, D.R., 1990, Batch Leaching studies of Rundle oil shale. J. Environ. Qual., 19: 408-413.

Kilkelly, M.K., and W.L. Lindsay, 1982, selected Trace Elements in Plants Grown on Retorted Oil shale. J. Environ. Qual., 11: 422-427.

Knutson, C.F., G.F. Dana, G. Solti, J.L. Qian, F.D. Ball, A.C. Hutton, J. Hanna, P.I. Russell, and E.M. Piper, 1988, Developments in oil Shale 1987. Am. Assoc. Petrol. Geol. Bull., 72: 378-390. 
Koppenaal, D.W., K. Cisler, and G. Thomas, 1981, Leaching studies on Kentucky oil Shale Products, in 1981 Eastern oil Shale symp. Proc., Institute for Mining and Minerals Research, Lexington, KY, 369-382.

Mattigod, S.V., and A.I. Page, 1983, Assessment of Metal Pollution in Soils, in Thornton, I., ed., Applied Environmental Geochemistry. Academic Press, London, England, 355-394.

Mattigod, S.V., G. Sposito, and A.L. Page, 1981, Factors Affecting the Solubilities of Trace Elements in Solls, in Doowdy, R.H., et al., eds., chemistry in the soil Environment. American society of Agronomy Spec. Publ. 40, Madison, WI, 203-221.

Mason, G.M., L.K. Spackman, and J.D. Williams, 1984, High Temperature Minerals in an In situ oil shale Retort, in Gary, J.H., ed., 17th oil shale symp. Proc., Colorado school of Mines Press, Golden, Co, $121-1.32$.

Merriam, N.W., C.Y. Cha, and S. Sullivan, 1987, Production of spent Shales by simulation of surface oil shale Retorting processes. Laramie, WY, WRI Report to DOE, DOE/FE/60177-2439.

Miknis, F.P., and R.E. Robertgon, 1987, Characterization of DOE Reference Oil Shales: Mahogany Zone, Parachute Creek Member, Green River Furmation oil Shale, and Clegg Creek Member, New Albany Shale. Laramie, WY, WRI Report to DOE, DOE/MC/11076-2448.

Nordstrom, D.K., and E.A. Jenne, 1977, Fluorite Solubility Equilibria in Selected Geothermal waters. Geochim. Cosmochim. Acta, 41: 175-188.

Nordstrom, D.K., L.N. Plummer, T.M.I. Wigley, T.J. Wolery, J.W. Ball, E.A. Jenne, R.L. Bassett, D.A. Crerar, T.M. Florence, B. Fritz, M. Hoffman, G.R. Holdren Jr., G.M. Lafon, S.V. Mattigod, R.E. McDuff, F. Morel, M.M. Reddy, G. Sposito, and J. Thrailkill, 1979, Comparison of Computerized Models for Equilibrium Calculations in aqueous systems, in Jenne, E.A., ed., Chemical Modeling in Aqueous systems. Am. Chem. Soc. Symp. Ser. 93, Washington, DC, 857-894.

Paciorek, K.L., P.F. Kimble, S.R. Masuda, H.M. Atkins, R.H. Kratzer, and J. Westoff, 1983, The Reactivity of Pyrite in Raw Eastern Oil Shale and Its Transformation During Processing. 1983 Eastern oil Shale symp. Proc., Institute for Mining and Minerals Research, Lexington, $\mathrm{KY}, 281-285$.

Park, W.C., A.E. Lindemanis, and G.A. Robb, 1979, Mineral Changes During Oil Shale Retorting. In Situ, 3: 353-381.

Rammler, R.W., 1982, The Lurgi-Ruhrgas Process for the Retorting of oil Shale, in Allred, V.D., ed., oil shale Processing Technology. The Center for Professional Advancement, East Brunswick, NJ, 83-105.

Reddy, K.J., and W.I. Lindsay, 1986, The Solubility Relationships of Calcium and Magnesium Minerals in Processed Oil Shales. J. Environ. Qual., 15: 1-4. 
Reddy, K.J., and W.L. Lindsay, 1987, Availability and Plant Uptake of Trace Elements from Recarbonated Retorted Shale. J. Environ. Qual., $16: 168-171$.

Reddy, K.J., W.L. Iindsay, F.W. Boyle Jr., and F.F. Redente, 1986 , Solubility Relationships and Mineral Transformations Associated with Recarbonation of Retorted Shales. J. Environ. Qual., 15: 129-133.

Reddy, K.J., and V.R. Hasfurther, 1989, Solubility and Release of Fluorine and Molybdenum from oil shale Solid Wastes. Water Res., $23: 833-836$.

Reddy, K.J., J.I. Drever, and V.R. Hasfurther, 1989, Application of a Geochemical Model to the Prediction of the chemistry of Extracts from Non-Recarbonated and Recarbonated spent Shales. Laramie, WY, WRI Report to DOE, DOE/MC/11076-288\%.

Richardson, S.G., C.M. MeKell, M.R. George, and G. Gray, 1981, weathering Effects on some chemical and Physical properties of Retorted oil Shale. J. Environ. Qual., 10:221-224.

Robl, T.L, Field and Laboratory Leaching studies of Retorted Kentucky Oil Shales. U.S. Department of Energy Report under contract DE-FC$84 \mathrm{MC} 21144$, in press.

Robl, T.L., K. Cisler, G. Thomas, and D. Koppenaal, 1985, Leaching Characteristics of Eastern Oil Shale: First Year Data summary of the Hope Creek study. 1985 Eastern oil shale symp. Proc., Institute for Mining and Minerals Research, Lexington, KY, 117-129.

Robl, T., J. Obley, G. Thomas, W. Jones, and M. Shirav, 1986, Elemental Release Characteristics of Eastern Oil Shales: Comparison of Field and Laboratory Results. 1986 Eastern oil Shale symp. Proc., Institute for Mining and Minerals Research, Lexington, KY, 231-243.

Robl, T., J. Obley, B. Schram, G. Thomas, and J. Kung, 1987, Leachate Composition and Elemental Release Pattern for Eastern oil shale Materials from the Hope creek Field study. 1987 Eastern oil shale symp. Proc., Institute for Mining and Minerals Research, Lexington, $\mathrm{KY}, 59-66$.

Routson, R.C., R.E. Wildung, and R.M. Bean, 1979, A Review of the Environmental Impact of Ground Disposal of oil shale Wastes. J. Environ. Qual., 8: 14-19.

Saether, O.M., and D.D. Runnells, 1980, Geochemistry of Fluorine in oil Shale Leachates, in Gary, J.H., ed., 13th oil shale symp. Proc., Colorado School of Mines Press, Golden, CO, 362-268.

Saffer, A., J. Siler, and D. Bhattacharyya, 1982, Leaching Behavior of Retorted and oxidized Eastern Oil Shale. 1982 Eastern oil shale Symp. Proc., Institute for Mining and Minerals Research, Lexington, KY, $283-288$. 
Schwab, A.P., W.I. Lindsay, and P.J. Smith, 1983, Elemental contents of Plants Growing on Sofl-covared Rotorted Shale. J. Environ. Qual., 12: $301-304$.

Smith, J.W., W.A. Robb, and N.B. Young, 1978, High Temperature Reactions of oil shale Minerals and Their Benefit to Oil shale Processing in Place, in Gary, J.H., ed., 11th oil shale symp. Proc., Colorado School of Mines Press, Golden, Co, 100-112.

Sobek, A.A., M.A. Bambenek, and D. Meyer, 1982, Modified Soxhlet Extractor for Pedologic Studies. Soil Sci. Soc. Am. J., 46: 13401342 .

Spackman, L.K., and M.E. Essington, 1988, Trace Element Partitioning in Density-Fractionated processed Green River Formation oil shale: Assessment of Solid Phase Elemental Associations, in Lazar, D.J., ed., 1988 Eastern oil shale symp. Proc., Institute for Mining and Minerals Research, Lexington, KY, 163-176.

Sposito, G., 1984, Chemical Models of Inorganic pollutants in soils. CRC Reviews in Environ. Control, 15: 1-25.

Sposito, G., and S.V. Mattigod, 1980, GEOCHEM: A Computer program for the Calculation of Chemical Equilibria in soil solutions and other Natural water systems. The Kearney Foundation of soil science, Univ, of Calif., Riverside, CA.

Stark, J.M., and E.F. Redente, 1986, Trace Element and salt Movement in Retorted oil Shale Disposal Sites. J. Environ. Qual., 15: 282-288.

Stark, J.M., and E.F. Redente, 1990a, Plant Uptake and Cycling of Trace Elements on Retorted Oil Shala Disposal Piles. J. Environ. Qual., 19 : 495-501.

Stark, J.M., and E.F. Redente, 1990b, Copper Fertilization to prevent Molybdenosis on Retorted Oil Shale Disposal Piles. J. Environ. Qual., 19: 502-504.

Stol lenwerk, K.G., and D.D. Runnells, 1981, Composition of Leachate from Surface-Retorted and Unretorted Colorado oil shale. Environ. Sci. Technol., 15: 1340-1346.

Sullivan, P.J., and A.A. Sobek, 1982, Laboratory Weathering studies of Coal Refuge. Miner. Environ., 4: 9-16.

Sullivan, P.J., S.V. Mattigod, and A.A. Sobek, 1986, Dissolution of Iron Sulfides from Pyritic Coal Waste. Environ. Sci. Technol., 10: 10131016 .

Sullivan, P.J., J.L. Yelton, and K.J. Reddy, $1987 a$, solubility Relationships of Aluminum and Iron Minerals Associated with Acid Mine Drainage. Environ. Geol. Water Sci., 11: 283-287. 
sullivan, P.J., J.I. Yelton, and K.J. Reddy, 1987b, Iron sulfide oxidation and the chemistry of Acid Generation. Environ. Geol. Water Sci., 11: 289-295.

Sullivan, P.J., J.I. Yelton, and K.J. Reddy, 1987c, Acid Mine Drainage Potential of Raw, Retorted, and Combusted Eastern oil shale. Laramie, WY, WRI Report to DOE, DOE/LC/11062-2660.

Tian, J., and W.D. Ehmann, 1984, Elemental Release from Kentucky Raw and Retorted Shales by Leaching. 1984 Eastern Oil Shale Symp. Proc., Institute for Mining and Minerals Research, Lexington, KY, 207-215.

Tuttle, M.L., W.E. Dean, and D.J. Ackerman, 1985, An Evaluation of the Effects of Weathering on a 50-Year-old Retorted oil-shale Waste Pile, Rulison Experimental Retort, Colorado, in Gary, J.H., ed., 18 th oil shale symp. Proc., Colorado school of Mines Press, Golden, Co, $338-346$.

Williamson, D.L., D.C. Melchior, and T.R. Wildeman, 1980, Changes in Iron Minerals During Oil-Shale Retorting, in Gary, J.H., ed., 13th oil shale symp. Proc., Colorado school of Mines, Golden, Co, 337350 . 
APPENDIX 

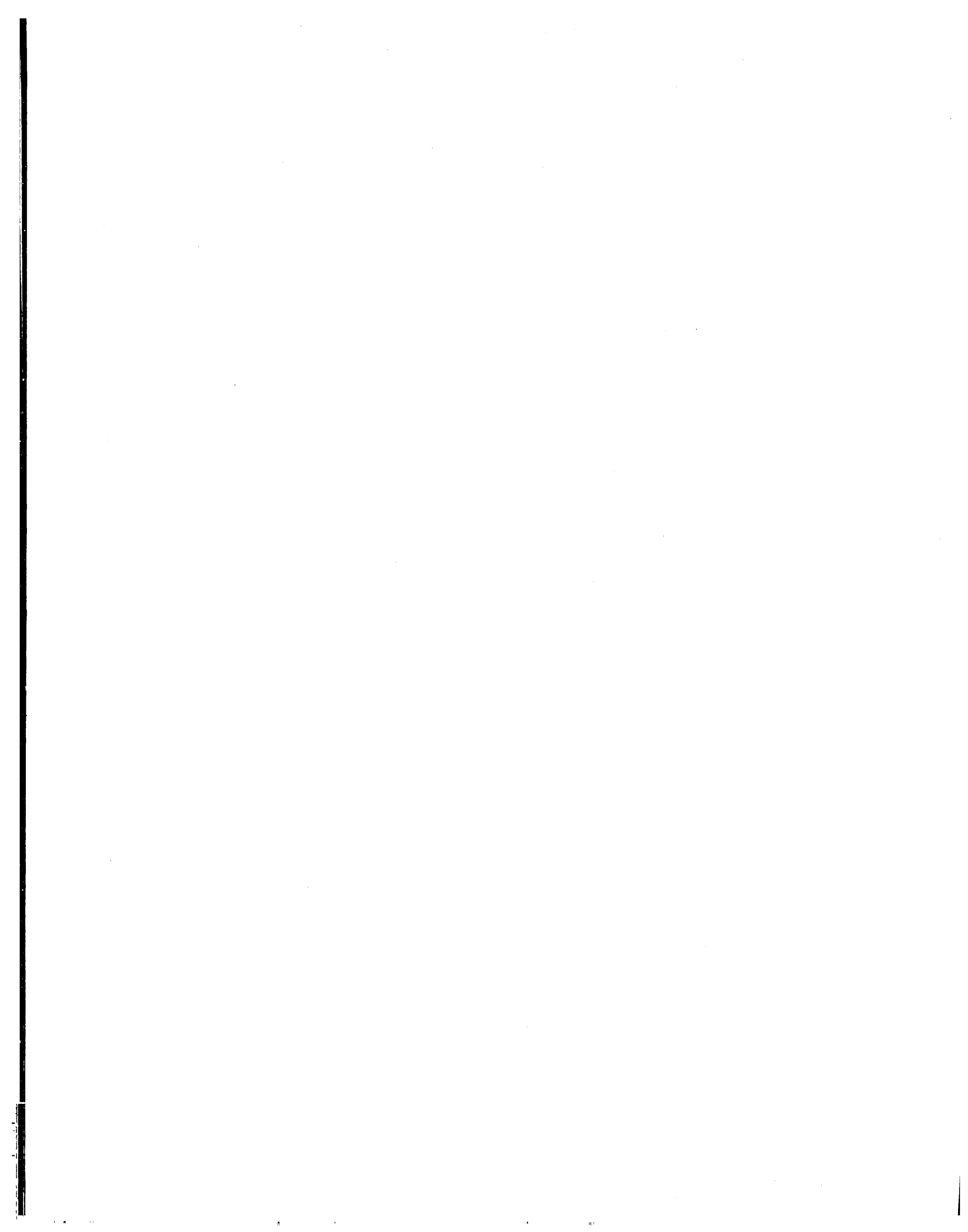